September 2000

\title{
Unemployment and Wage Rigidity when Labor Supply is a Household Decision
}

\author{
Kaushik Basu ${ }^{1}$, Garance Genicot ${ }^{2}$ and Joseph E. Stiglitz
}

\begin{abstract}
$\underline{\text { Abstract }}$
If people's labor-supply decisions are taken at the level of the household, it is natural to expect aggregate demand and unemployment to influence the supply curve of labor. An increase in unemployment could prompt households to send more workers out in search of work to insure against the risk of the primary worker getting unemployed (the 'added worker effect'). But it could also discourage people from wasting energy searching for work (the 'discouragement effect'). While these effects have been studied empirically, their theoretical bases remain largely unexplored. The present paper formally models household labor supply decisions and establishes sufficient conditions for the domination of one effect over the other. A number of surprising results are established, such as the possibility of multiple equilibria in the labor market and how the announcement of a minimum wage policy can result in an overall lowering of wages and also give rise to an equilibrium which displays, simultaneously, excess demand and excess supply of labor. The model shows how the empirical literature may have a bias in overestimating the strength of the discouragement effect. It also provides a framework for analyzing the effects of minimum wage policy and the provision of unemployment benefits. It is argued that certain kinds of unemployment benefits can be justified on grounds of efficiency.
\end{abstract}

JEL Classification Numbers: D10, J64, K31.

Key Words: added worker, labor supply, unemployment, minimum wage, efficiency wage.

Acknowledgements: The authors are grateful to two anonymous referees, Pranab Bardhan, Gary Becker, Francois Bourguignon, David Easley, Aaron Edlin, James Foster, Gus Ranis, Arijit Sen, Kunal Sengupta, E. Somanathan and T.N. Srinivasan for their comments. The paper has also benefited from seminar presentations at Yale University, the Indian Statistical Institute, the University of California-Berkeley, George Washington University, Johns Hopkins University, and the University of Southern California.

\footnotetext{
${ }^{1}$ Cornell University

${ }^{2}$ University of California at Irvine

${ }^{3}$ Brookings Institution and Stanford University
} 


\section{Unemployment and Wage Rigidity when Labor Supply is a Household Decision}

\section{INTRODUCTION}

In economics textbooks one learns to derive supply curves and demand curves in separate chapters. Such compartmentalization, however, renders the textbook model of markets unusable in many domains of real life in which demand and supply turn out to be interdependent. As early as 1950, Harvey Leibenstein, motivated by Thorstein Veblen's classic The Theory of the Leisure Class, had noted that, for many goods, a fall in supply may boost demand because there is "snob value" in being able to have what others cannot.

Nowhere is this interdependence more important than in labor markets. This happens because in labor markets each household takes decisions for several individuals, and within each household there occurs a certain amount of cooperation and consumption sharing. Suppose aggregate demand for labor falls. It is then quite natural to expect that a household which had thus far kept its women and children out of the labor force may now send them out in search of work to provide 'insurance' against the risk of the adult male members becoming unemployed. On the other hand, a lower likelihood of finding a job may discourage some potential workers from searching for work. The aim of this paper is to theoretically model these kinds of supply effects and to demonstrate how in the presence of these effects standard labor market policies may give rise to paradoxical market response.

The fact that an increase in unemployment can cause an increase in labor supply, thereby exacerbating the unemployment problem, has long been known. It is called the 
"added worker effect". From the forties till recent times, numerous empirical studies have investigated the effect of unemployment on labor supply. But the theoretical foundations of these works have not been spelled out. As a consequence some very natural implications of the added worker effect seem to have gone unnoticed in the literature. The need for a full-fledged theoretical analysis arises for three reasons. First, there is the innate worth of identifying and modeling the principles of consumer theory generating these labor supply effects. Second, the added worker effect has some surprising implications which need to be understood if we are to devise effective policy interventions. Third, a theoretical model may allow us to devise more sophisticated tests for the added worker effect, which continues to be an area of much empirical dispute.

To give the reader a preview of this paper, let us begin by stating, in outline, one of the results that we obtain formally later. Assume, as seems natural, that greater unemployment (for instance, among adult males) prompts women and children to join the labor force. Now start from a full-employment situation, with wage at some level, say w. It is shown in the paper that, if a legal minimum wage is announced at some wage rate $\hat{\mathrm{w}}$, which is below $\mathrm{w}$, then market wage can fall from $\mathrm{w}$ to $\hat{\mathrm{w}}$ and this can give rise to unemployment. Conversely, the abolition of a legal minimum wage can cause the market wage to rise. Moreover, a rise in the legal minimum wage can actually lead to a fall in unemployment despite the model being that of competition.

At first sight such results may seem academic, for we may wonder why governments would ever impose a legal minimum wage below the prevailing market wage. In reality labor markets are often segmented, with different wages prevailing in different markets - for instance, agricultural wages may be lower than the wages that 
prevail in the manufacturing sector. Suppose in some fringe sector wage happens to be low. Now, minimum wage laws are typically used to boost wages in such "depressed" sectors. So a legal minimum wage below the wage that prevails in the main labor market but above the wage in the fringe market is not at all uncommon. This is obviously true for countries, such as the United States, where there is a unique minimum wage that applies to all sectors. But even when that is not the case and the minimum wage is made sector or region specific it is arguable that there is so much variation in any real economy that even within a single sector or region there will be sub-segments of the labor market where the free market wage exceeds the legal minimum wage. In addition, our analysis also applies to models where the wage rigidity comes from an endogenous efficiency wage argument, instead of a legal minimum wage. For this reason we believe that the effect we are writing about is likely to be important in reality.

The plan of the paper is as follows. In Section 2 we recapitulate some of the related literature and empirical findings. In Section 3 an intuitive sketch of our model is developed and the paradoxical result concerning the effects of minimum wage legislation is established. Section 4 constructs a formal mathematical model, with the sections thereafter endogenizing the wage rigidity and drawing out several implications of the model such as how giving unemployment benefits can increase efficiency.

\section{THE BACKGROUND}

The effect of one person's employment status on the decision of other members of the household to look or not look for employment was recognized and attempted to be measured by Woytinsky (1940a, see also 1940b). In the words of Humphrey (1940, p. 
412), what Woytinsky was getting at was "the familiar story of the head of the family losing his job whereupon his wife and children also start looking for work so that two or more persons appear to be unemployed and are reported to be unemployed by most censuses".

Starting with this exchange in the forties, this topic became a subject of considerable empirical investigation and debate (see, for instance, Mincer, 1962; Belton and Rhodes, 1976; Ashenfelter, 1980; Layard, Barton and Zabalza, 1980; Bardhan, 1984; Lundberg, 1985; Maloney, 1987, 1991; and Tano, 1993). This effect, of one person's (the 'primary' worker) unemployment, or potential unemployment, prompting other family members (the 'secondary' workers) to seek work, came to be known as the 'added worker effect'. Economists subsequently went on to argue about an opposing force, which has come to be called the 'discouragement effect'. This is the response of potential workers losing hope and ceasing to search for jobs, when they see a lot of unemployment around them. The strength of these two effects is a matter of debate.

The empirical results are mixed. There seems to be some consensus, or at least a majority opinion among those involved in empirical research in this area, that the discouragement effect is very strong and frequently offsets entirely the added worker effect (see for instance Humphrey, 1940; the discussion in Layard et al., 1980; and Maloney, 1991). But others, like Tano (1993), find that both effects are significant and coexist. However there is reason to believe that the empirical literature has tended to underestimate the added worker effect. Most studies investigate the effect of actual unemployment of husbands on the actual employment of women. First, it is important to realize that a more meaningful approach is to investigate the desired hours of work of the 
wife, since the wife's actual employment may also be affected by the increase in unemployment (that is, she may not be able to actually find work). Once this is done, the results can already look different. Maloney (1987), for instance, using reported data on underemployment finds a significant added worker effect. Second, the added worker effect does not arise solely because of actual unemployment of the primary worker, but might be a response to the worsening job prospects of the primary worker. It is on the former that most empirical studies have been in effect focusing. A major conceptual difference between our model and the standard literature is that we emphasize the households' and their secondary workers' response to the worsening job prospects of the primary worker.

One way to empirically differentiate between the two would be to take two points of time where macro unemployment rates are significantly different. Then by focusing on households for which the primary worker's status is unchanged between these two time periods, we can check if there is a systematic change in the labor supply of the secondary workers of these households. Note that, it is in this spirit that Lundberg (1985) studies the effect of employment uncertainty and credit constraint in creating short-run participation and employment patterns. The estimates are based on employment transition probabilities rather than static measures of labor supply and the results show a small but significant added worker effect.

Finally, we shall show below that once a theoretical model of household supply response is constructed, we could add plausible features to it which can explain why the added worker effect can create an empirical illusion of there being a discouragement effect. In reality we would expect both effects (added worker and discouragement) to be 
present, but our analysis explains why the discouragement effect may appear larger than it actually is.

Surprisingly little has been written on this specific topic theoretically. An early attempt is Ashenfelter (1980) that analyzed the comparative static effect of one person's labor supply being constrained on another household member's supply. This paper fits into the growing literature emphasizing the inter-dependence of decisions within households. For instance, in Basu and Van (1998) and Basu, (1999) the effect of adult labor market conditions on the incidence of child labor is analyzed, using a model of household-based decision making.

The present paper builds a theoretical model which explicitly allows for the added worker effect, highlights some paradoxical results, shows why the discouragement effect may be, in part, illusory, and relates these ideas to other areas of research such as efficiency wage and inflation, unemployment benefits, and race and gender issues.

\section{A SPECIAL CASE: MINIMUM WAGE AND UNEMPLOYMENT}

Since the novelty of our results arise from the labor supply decision, let us suppose that the aggregate demand for labor is the usual downward-sloping function of wage, w, denoted by $\mathrm{D}(\mathrm{w})$.

What we have to model carefully is the 'supply curve'. Let us consider an economy with many households, each household i consisting of m potential workers. When we want to be explicit about the sex and age of the workers we will think of person 1 in each household as the adult male, person 2 as the adult female, and the rest as the 
children. In case this is a society where children do not work, we may think of a household's members $3,4, \ldots, \mathrm{m}$ as the children who are above 16 years of age.

Recall how the textbook supply curve of labor is derived. We take the market wage, w, to be arbitrarily given and make the household do a maximization exercise and work out the household's labor supply. There is an implicit assumption in such an exercise. The assumption is that a person who supplies his or her labor gets to work. This assumption becomes unrealistic if there is unemployment in the economy. It is for this reason that some economists have worked out the household's supply, taking as given the fact that some members may be supply-constrained.

We shall proceed in the same spirit but conceive of a different model. We shall assume that the level of unemployment in the economy is public knowledge. If the unemployment rate (expressed as a fraction) is $\mathrm{u}$, then we shall take $1-\mathrm{u}=\mathrm{p}$ to be the probability of each worker finding a job. Let us assume that this is the same for those who are currently employed and those who are currently unemployed. This assumption is used in the well-known Harris-Todaro model (Harris and Todaro, 1970). If we think of this as a casual labor market with large turnover then this is not an unrealistic assumption. If a fraction $\mathrm{p}$ of all those supplying their labor currently find jobs, it seems reasonable to suppose that each worker treats $\mathrm{p}$ as the probability of being employed in the next period. We shall assume that just as each household is a wage-taker, each household is a p-taker (that is, it ignores the effect of its own decision on the aggregate unemployment rate in the economy). This being so it is quite reasonable to suppose that individual labor supply decision will depend on $\mathrm{w}$ and $\mathrm{p}$ (and not only on $\mathrm{w}$ ). This is especially so when decision making occurs at the level of the household. For ease of thinking, let us suppose each 
person sees $\mathrm{w}$ and $\mathrm{p}$ and then has to decide (even if this is a household-based decision) whether to supply his or her labor or not.

It seems reasonable to suppose that if $\mathrm{p}$ is low, the household faces a genuine risk of the primary worker not finding a job. It is then reasonable for some of the other members of the household to supply their labor as well (so as to minimize the risk of the household being left with no one employed). This added worker effect seems not to have been modeled theoretically and its full implications have not been studied. ${ }^{2}$ So let us proceed to take explicit account of this. We later construct a general model in which the added worker effect dominates only in a class of special situations, and the demand curve takes a more complex form.

Leaving formal mathematical modeling to later, we may assert that the above consideration will mean that household i's total labor supply, $\mathrm{s}_{\mathrm{i}}$, will depend on $\mathrm{w}$ and $\mathrm{p}$ and as $\mathrm{p}$ falls $\mathrm{s}_{\mathrm{i}}$ will rise. By aggregating the labor supply of all households we may write

$$
\mathrm{S}(\mathrm{w}, \mathrm{p}) \leq \mathrm{S}\left(\mathrm{w}, \mathrm{p}^{\prime}\right) \quad \text { for all } 0<\mathrm{p}^{\prime}<\mathrm{p} \leq 1
$$

where $\mathrm{S}$ is the aggregate supply or, assuming that the aggregate supply is continuously differentiable,

$$
\mathrm{S}(\mathrm{w}, \mathrm{p}), \frac{\partial \mathrm{S}}{\partial \mathrm{p}} \leq 0
$$

At this stage $\frac{\partial \mathrm{S}}{\partial \mathrm{p}} \leq 0$ is simply an assumption. Since this added worker effect assertion (that a worsening in job prospects results in an increased labor supply) is so central to our paper, it would be unfortunate if this remained at the level of an axiom. In the next section we show that under a large class of standard neo-classical assumptions, with no 
transaction or sunk cost, $\frac{\partial \mathrm{S}}{\partial \mathrm{p}} \leq 0$ is a property that can be deduced. But for now let us continue to treat this as an assumption. We shall later show that once transactions or sunk costs are allowed $\frac{\partial S}{\partial p}$ can be positive, thereby creating a general model which can explain both the added worker effect and the discouragement effect.

The textbook supply curve of labor is the relation between $\mathrm{w}$ and $\mathrm{p}$ when $\mathrm{p}=1$. Figure 1 shows this curve as OA. We do not insist on any particular shape for this. If we want to think of this as perfectly inelastic (with only adult males working) it will be a vertical straight line. If we believe supply curves bend backwards at high wages, we could build that into our model.

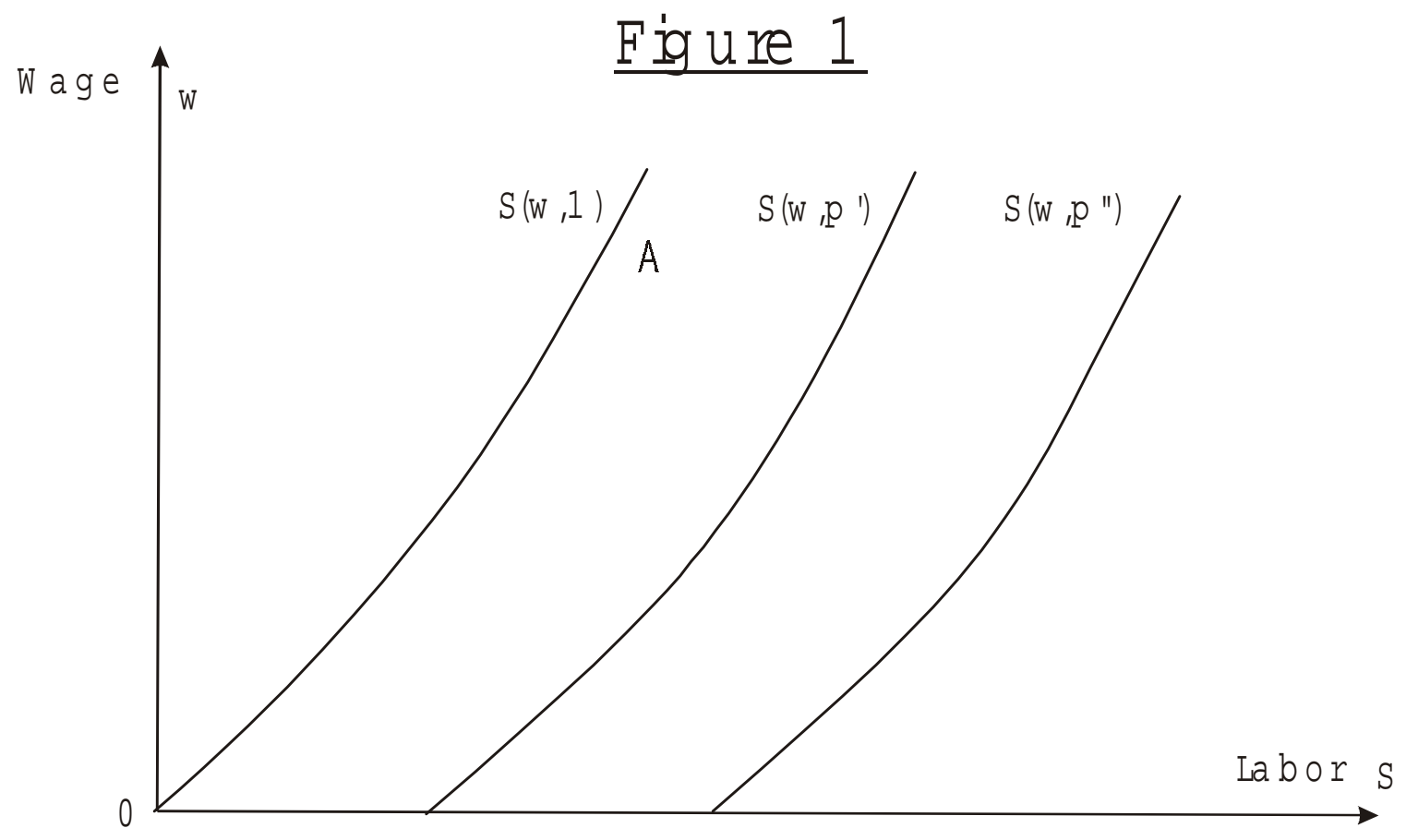

Next note that, for each $\mathrm{p} \in[0,1]$, we can draw a supply curve $S=S(w, p)$. We shall call each such curve a "quasi-supply curve" or "p-supply curve". Figure 1 illustrates a family of p-supply curves. If we wanted to model the discouragement effect of 
unemployment, we would take $\frac{\partial S}{\partial p}>0$ and so, as $p$ fell, the $p$-supply curves would move left. If we believed that for low wages the added worker effect is dominant and for high wages the discouragement effect dominates, we would have the p-supply curves intersecting one another. Let us however, for now, go along with the assumption $\frac{\partial S}{\partial p} \leq 0$.

Our aim now is to construct the "actual (aggregate) supply curve" from the psupply curves. This will, interestingly, depend on the nature of the demand curve, thereby illustrating our initial observation regarding the inter-dependence of demand and supply.

Let the demand curve, $\mathrm{D}(\mathrm{w})$, be as shown in Figure 2. Now, given any point on any p-supply curve, we can easily work out the rate of employment that will actually come to prevail. Suppose for instance, we are at point $b$. Then labor supply is $\hat{w} b$ and (given the wage implicit at b) labor demand is $\hat{w} \mathrm{k}$. Hence the rate of employment or probability finding a job is given by $\frac{\hat{\mathrm{w} k}}{\hat{\mathrm{w} b}}$. Note that $\mathrm{b}$ is a point on the $\mathrm{p}^{\prime}$-supply curve. Hence, if $\frac{\hat{w k}}{\hat{w} b}$ is not equal to $p^{\prime}$, labor supply can never occur at $b$.

By this reasoning, note that the probability of finding work at point a is 1 and at point $\mathrm{c}$ it is 0 (since demand for labor at $\mathrm{c}$ is zero). It follows that when we move from a to $\mathrm{c}$ along the p'-supply curve there must occur (given the continuity of the demand and p'-supply curve) some point where the probability of finding work is exactly equal to p'. If the demand curve is downward sloping and the quasi-supply curve upward sloping (and one of these strictly so), then this happens at a unique point of each p-supply curve where $\mathrm{p}<1$. Let us assume that for the $\mathrm{p}^{\prime}$-supply curve this happens at $\mathrm{b}$. That is, 
$\hat{\mathrm{w} k} / \hat{\mathrm{w}} \mathrm{b}=\mathrm{p}^{\prime}$. We could then think of $\mathrm{b}$ as a point on the actual supply curve. It is a point that satisfies rational expectations. Suppose the wage happens to be $\hat{\mathrm{w}}$. If all workers expect the rate of employment to be $\mathrm{p}^{\prime}$, then their supply would be such that the expectation is confirmed.

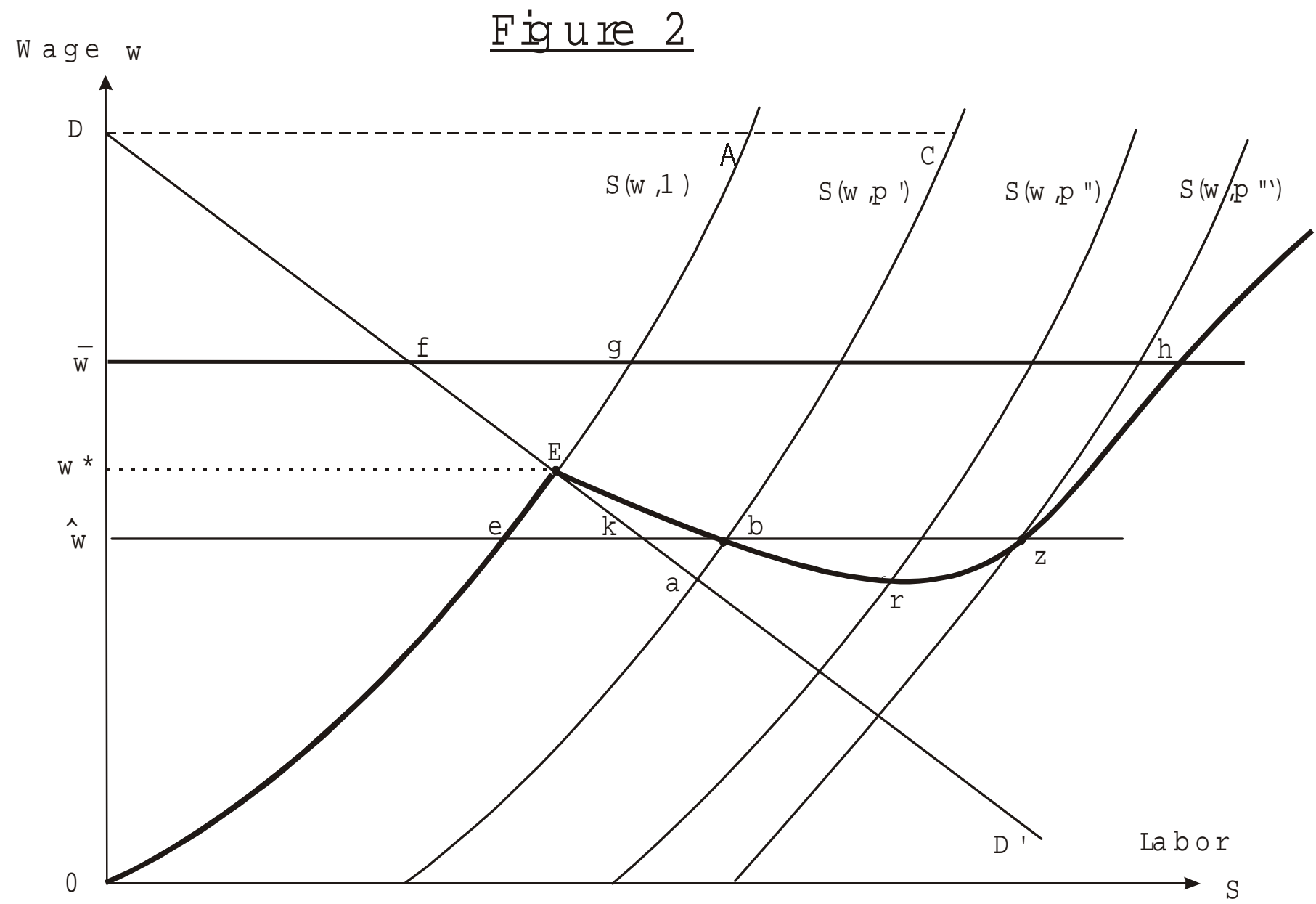

If on each quasi-supply curve we pick the point that satisfies rational expectation and join up such points what we get is the actual aggregate supply curve of labor. Let the thick line going through 0 and $b$ be such a curve.

It may be worthwhile explaining why the aggregate supply curve coincides with the 1-supply curve (that is the p-supply curve corresponding to full employment) to the 
left of the demand curve. This is because at any such point, for example, e, demand for labor exceeds supply and so the rate of employment is 1 .

Let us now demonstrate some of the paradoxical results that this model gives rise to. Suppose DD' in Figure 2 represents the demand for labor. If wages are fully flexible, then $\mathrm{E}$ represents the only point of equilibrium. The wage is $\mathrm{w}^{*}$ and demand equals supply. Now suppose government enacts a minimum wage law and sets the legal minimum wage at $\hat{\mathrm{w}}$. Since $\hat{\mathrm{w}}<\mathrm{w}^{*}$, standard economics would lead us to expect that this cannot possibly have any impact (Mincer, 1976; Ashenfelter and Blum, 1976). But in this model, where there are added worker effects, this legal intervention can have significant consequences.

Observe that if wage were at $\hat{\mathrm{w}}$, there are three levels of supply that would satisfy rational expectations. These are $\hat{\mathrm{w}} \mathrm{e}, \hat{\mathrm{w}} \mathrm{b}$, and $\hat{\mathrm{w} z}$. Suppose $\hat{\mathrm{w} b}$ is the supply that actually occurs. Then supply exceeds demand and so wages have a tendency to fall, but the law will not allow it to fall. So the wage persists at $\hat{\mathrm{w}}$ and there is open unemployment. So point $b$ depicts an equilibrium. Point e does not depict an equilibrium because, though it satisfies rational expectations, at e there is excess demand for labor and so wage would rise. By this same logic point $\mathrm{z}$ depicts an equilibrium. Of course the earlier equilibrium at $\mathrm{E}$ is still available. In other words, the minimum wage law gives rise to multiple equilibria and, in particular, a legal minimum wage, imposed at a level below the prevailing market wage, can result in a fall in the wage. Note that among b and $\mathrm{z}, \mathrm{b}$ is an unstable equilibrium. A small rise in unemployment at $\mathrm{b}$ will result in more unemployment and the equilibrium would finally settle at $\mathrm{z}$ which is a stable equilibrium. 
Let us now check what happens if the minimum wage is set above ${ }^{*}$, for instance at $\overline{\mathrm{W}}$. Standard theory would predict an unemployment level of fg. But supply occurs at point $g$ only if the probability of finding work is one. As soon as there is unemployment, supply will begin to change. Hence, our model predicts an unemployment level of fh.

Another interesting result arises if this model is combined with an efficiency wage model. Consider either a labor turnover model or a Leibensteinian model (Leibenstein, 1957; Mirrlees, 1975; Stiglitz, 1974, 1976; and Fehr, 1986) in which a worker's productivity happens to depend on his wage, ignoring for now the fact that a part of this wage may go to feed other members of the household. The latter is discussed in Genicot (1998). We will, later in the paper construct a model which combines a model of household decisionmaking, as discussed above, along with a theory of endogenous wage rigidity of a fairly standard kind. Let us for now suppose that the efficiency wage is at $\hat{\mathrm{w}}$, and the aggregate demand for labor is $\hat{\mathrm{w}} \mathrm{k}$. For wages above $\hat{\mathrm{w}}$, aggregate labor demand is given by the line Dk.

Let us suppose the supply conditions are as shown in Figure 2. Thus the standard textbook supply curve is given by OA. Our first expectation may be that, since at the efficiency wage labor demand exceeds $\hat{w}$, wage will rise above $\hat{\mathrm{w}}$, the efficiency wage, and there will be no involuntary unemployment. However, in our model, wage may persist at $\hat{\mathrm{w}}$ with unemployment equal to kb or, more likely kz. Of course at this wage, workers will be willing to work for a lower wage, but employees will not accept such offers.

It should also be transparent that the aggregate supply curve of labor depends on the nature of the demand curve. To see this, suppose the wage is fixed at $\hat{\mathrm{w}}$ (Figure 3 ) 
and the economy is at the equilibrium $\mathrm{A}$. Consider a drop in the labor demand from $\mathrm{D}_{1}$ to $\mathrm{D}_{2}$. To $\hat{\mathrm{w}}$ corresponds a labor demand $\lambda$ smaller than $\mathrm{k}$. Hence $\mathrm{A}$ no longer belongs to the actual aggregate supply curve since $\frac{\hat{\mathrm{w}} \lambda}{\hat{\mathrm{w} A}}<\frac{\hat{\mathrm{w} k}}{\hat{\mathrm{w} A}}=\mathrm{p}$. The point on $\mathrm{S}(\mathrm{w}, \mathrm{p})$ which will translate in an actual probability of finding work of $\mathrm{p}$ is now A'. It is easy to check that a fall in demand will result in the supply curve moving down (everywhere to the right of the demand curve). Starting from A, a decrease in the demand worsens people's expectations about the likelihood of finding a job. In response they will increase their labor supply causing the unemployment to rise by more than the fall of demand and the economy will settle in a new equilibrium B.

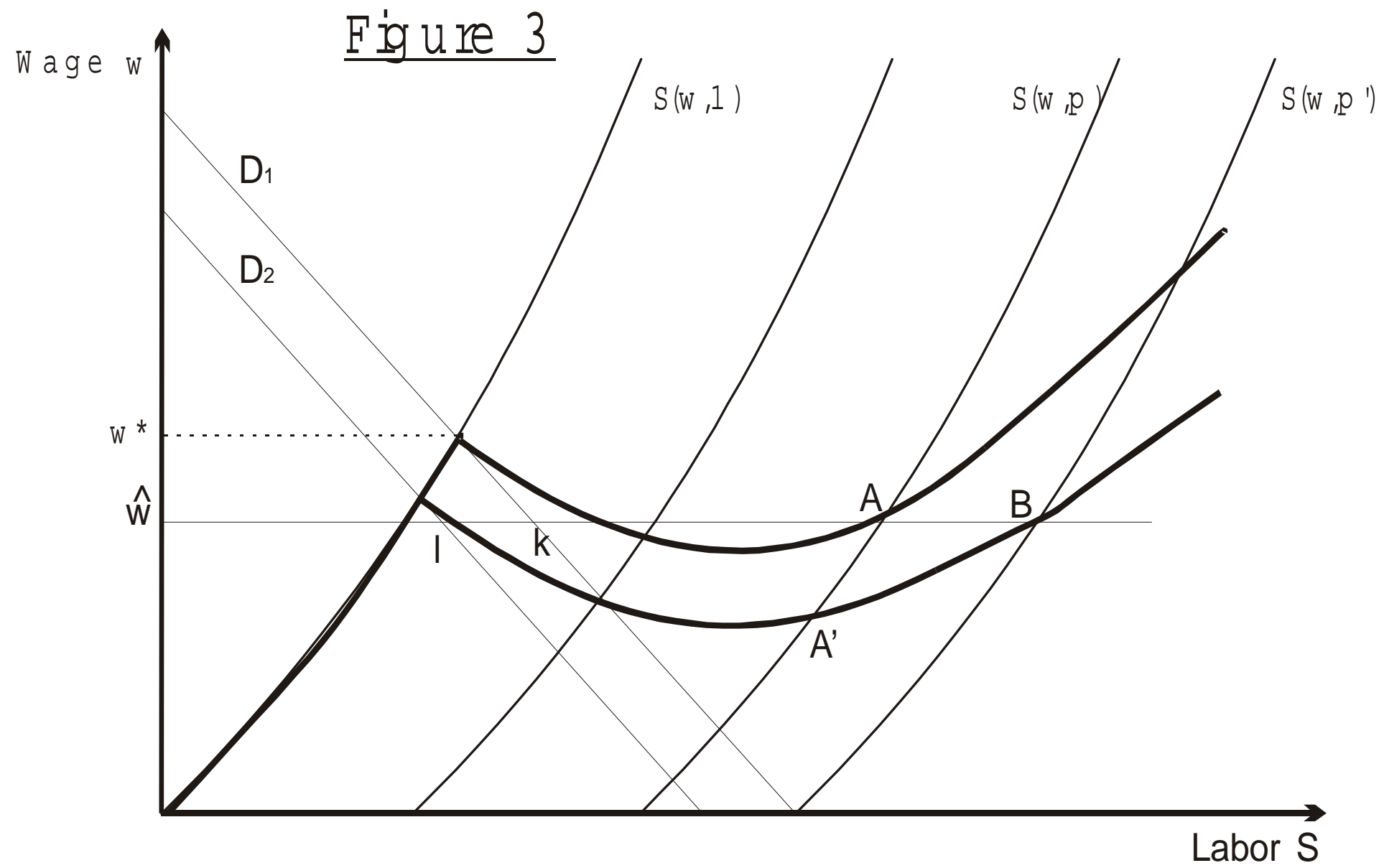




\section{GENERAL MODEL}

In this economy there are $\mathrm{h}$ identical households and each household has $\mathrm{m}$ members. Each member $\mathrm{i}$ is endowed with one unit of labor and has a disutility of labor equal to $c_{i}$. If it is the case that the adult male is the first to go out to work, we could suppose that person 1 in each household is the adult male and so $c_{1} \leq c_{i}$, for all $\mathrm{i}=1,2, \ldots, \mathrm{m}$. But without loss of generality, we will assume $\mathrm{c}_{1}=\mathrm{c}_{2}=\ldots=\mathrm{c}_{\mathrm{m}} \equiv \mathrm{c}$. If the total income of the household is $\mathrm{Y}$ and the total effort expended by the household is $\mathrm{C}$, then the household's utility, we will assume, is given by $\mathrm{V}(\mathrm{Y})-\mathrm{C}$, where $\mathrm{V}^{\prime}>0$, and $\mathrm{V}^{\prime \prime}<0$. If e household members are employed and earn a wage $\mathrm{w}$, the household derives a welfare $\mathrm{V}(\mathrm{ew})$ - ec from this employment. In addition there is a sunk cost of $\theta$ per person associated with searching for work. This $\operatorname{cost} \theta$ can originate from neglected housework, the costs of registering at an agency and subscribing to newspapers and employment gazettes, or acquiring some basic skills such as word processing. These are sunk costs because if one does not find the job one is looking for, the costs cannot be recovered.

It is assumed that the household is sufficiently small in comparison to the aggregate labor force that it takes the wage rate, $w$, and the probability of each person finding a job, $\mathrm{p}$, to be given. Let $\mathrm{W}(\mathrm{n}, \mathrm{p}, \mathrm{w})$ denote a household's expected welfare where $\mathrm{n}$ is the number of persons who supply labor (that is, search for jobs), $\mathrm{p}$ is the probability of each person finding employment and $\mathrm{w}$ is the market wage. The household's problem is to choose the number of household members, $\mathrm{n}$, to supply to the labor market, $\mathrm{n} \in$ $\{0,1, \ldots, m\}$. 
To understand the household's optimization problem, it is convenient to first work out an intermediate step. Suppose $\mathrm{n}$ persons from a household supply labor to the market (that is, they apply to the employment exchange for jobs). If, of these, k persons are offered work, the question that we want to answer, first, is: how many of these offers will not be accepted? Suppose to ensure against starvation a household chooses a large $n$ initially to apply for jobs at the employment exchange (that is, it sends out, for instance, not just the adults but also the children to look for work). If they then turn 'lucky' and find that virtually all $\mathrm{n}$ persons end up with job offers, (i.e. $\mathrm{k}$ is close to $\mathrm{n}$ ) it may not be in the household's interest to accept all these offers. How many will the household accept? Let us assume that turning down an offer (after registering with the employment exchange) entails a cost of $d(\geq 0)$ units to the household. In that case the household that gets $\mathrm{k}$ offers will accept $\mathrm{t}$ of these offers where $\mathrm{t}$ solves the following maximization problem

$$
\max _{\mathrm{t} \leq \mathrm{k}}[\mathrm{V}(\mathrm{tw})-\mathrm{tc}-(\mathrm{k}-\mathrm{t}) \mathrm{d}]
$$

With this in mind, and using $\pi(\mathrm{k} \mid \mathrm{n}, \mathrm{p})$ to denote the probability of $\mathrm{k}$ persons finding work (when $\mathrm{n}$ go out searching) and $\mathrm{p}$ the probability of each person finding work, we have

$$
\mathrm{W}(\mathrm{n}, \mathrm{p}, \mathrm{w})=\sum_{\mathrm{k}=0}^{\mathrm{n}} \pi(\mathrm{k} \mid \mathrm{n}, \mathrm{p}) \max _{\mathrm{t} \leq \mathrm{k}}[\mathrm{V}(\mathrm{tw})-\mathrm{tc}-(\mathrm{k}-\mathrm{t}) \mathrm{d}]-\mathrm{n} \theta
$$

where

$$
\pi(\mathrm{k} \mid \mathrm{n}, \mathrm{p})=\frac{\mathrm{n} !}{\mathrm{k} !(\mathrm{n}-\mathrm{k}) !} \mathrm{p}^{\mathrm{k}}(1-\mathrm{p})^{\mathrm{n}-\mathrm{k}}
$$


The household's problem is to choose $\mathrm{n} \in\{0,1, \ldots, \mathrm{m}\}$ so as to maximize (3). Let the household's choice be denoted by s(w,p). That is,

$$
\mathrm{s}(\mathrm{w}, \mathrm{p})=\underset{\mathrm{n}}{\arg \max } \mathrm{W}(\mathrm{n}, \mathrm{p}, \mathrm{w}) .
$$

Hence, the aggregate supply of labor is given by

$$
\mathrm{S}(\mathrm{w}, \mathrm{p})=\mathrm{hs}(\mathrm{w}, \mathrm{p})
$$

Let us now turn to the demand side. Suppose the aggregate demand for workers is $\mathrm{D}$ and $\mathrm{D}<\mathrm{S}$. Will all D workers, who get job offers, accept them? Certainly not.

To see this, it is useful to first solve (2). In order to do so, let us first define

$$
\mathrm{n}^{*}(\mathrm{w}) \equiv \underset{\mathrm{t}}{\arg \max }[\mathrm{V}(\mathrm{tw})-\mathrm{tc}-(\mathrm{k}-\mathrm{t}) \mathrm{d}]
$$

Note that $\mathrm{n}^{*}(\mathrm{w})$ does not depend on $\mathrm{k}$; it denotes the ideal number of persons in a household who would choose to work if a sufficiently large number get job offers. Since $\mathrm{V}$ is strictly concave, it follows that the $\mathrm{t}$ that solves (2) is equal to $\min \left\{\mathrm{n}^{*}(\mathrm{w}), \mathrm{k}\right\}$.

Now note that if the $\mathrm{D}$ workers who find work are picked randomly from the $\mathrm{S}$ workers looking for work (and we will, throughout the paper, make this randomness assumption), then any household in which more than $n^{*}(\mathrm{w})$ persons are offered work will decline some of those offers.

Let $\alpha$ denote the probability of a random chosen worker accepting an offer. Since, as we will presently see, $\alpha$ depends on $w$ and $p$, we will write it as $\alpha(w, p)$. Let us call a household a "k-chosen household" if $\mathrm{k}$ persons in the household get job offers. Note that the expected number of k-chosen households is given by $\mathrm{h} \pi(\mathrm{k} \mid \mathrm{s}(\mathrm{w}, \mathrm{p}), \mathrm{p})$, where $\pi$ is defined as in (4). Hence, the expected number of people, who belong to k-chosen households and are offered jobs, is given by $k h \pi(k \mid s(w, p), p)$. 
The probability of a person in a k-chosen household accepting a job offer is $\min \left\{\mathrm{n}^{*}(\mathrm{w}) / \mathrm{k}, 1\right\}$. From the definition of $\mathrm{p}$, we know $\mathrm{D} / \mathrm{hs}(\mathrm{w}, \mathrm{p})=\mathrm{p}$. From the three previous sentences we can calculate $\alpha$ as follows:

$$
\alpha(w, p)=\sum_{k=0}^{s(w, p)} \frac{\operatorname{kh} \pi(k \mid s(w, p), p)}{\operatorname{phs}(w, p)} \min \left\{\frac{n^{*}(w)}{k}, 1\right\}
$$

One simple result is that if $\mathrm{p}=1$, then $\alpha=1$. To prove this note that, if $\mathrm{p}=1$, then

$$
\pi(\mathrm{s}(\mathrm{w}, 1) \mid \mathrm{s}(\mathrm{w}, 1), 1)=1
$$

and

$$
\pi(\mathrm{k} \mid \mathrm{s}(\mathrm{w}, 1), 1)=0 \text {, for all } \mathrm{k}<\mathrm{s}(\mathrm{w}, 1) \text {. }
$$

Hence,

$$
\alpha(\mathrm{w}, 1)=\frac{\mathrm{s}(\mathrm{w}, 1) \mathrm{h}}{\mathrm{s}(\mathrm{w}, 1) \mathrm{h}} \min \left\{\frac{\mathrm{n}\left(\mathrm{w}^{*}\right)}{\mathrm{s}(\mathrm{w}, 1)}, 1\right\}
$$

Since $s(w, 1)$ is easily checked to be equal to $n^{*}(w)$, it follows that $\alpha(w, 1)=1$.

Let us now see how firms take their decisions. Without loss of generality we will assume that there is only one firm. This is a competitive model, so the firm is a taker of $\mathrm{w}$ and $\mathrm{p}$ and, hence, of $\alpha$. Given $\mathrm{w}$ and $\alpha$ the firm's problem is as follows.

Let $\mathrm{x}=\mathrm{f}(\mathrm{k})$ be the firm's production function, where $\mathrm{k}$ denotes the amount of labor used and $x$ the amount of output produced. We assume $f^{\prime}(k)>0, f^{\prime \prime}(k)<0$, for all $\mathrm{k} \leq 0$. The firm's problem is to decide how many job offers, $\mathrm{D}$, to make (keeping in mind that $\alpha$ is the probability of an offer being accepted). Hence, the firm's problem is to choose $\mathrm{D}$ so as to maximize its profit, $\mathfrak{R}$, where 


$$
\Re=\sum_{\mathrm{k}=0}^{\mathrm{D}} \pi(\mathrm{k} \mid \mathrm{D}, \alpha)[\mathrm{f}(\mathrm{k})-\mathrm{wk}]
$$

Unlike households, a firm, it is assumed, has to employ a person who accepts a job offered to him or her.

Let the solution of the above maximization problem be $\mathrm{D}(\mathrm{w}, \alpha)$

It will be evident from a theorem proved later that, w remaining the same, as $\alpha$ falls, $\mathrm{D}(\mathrm{w}, \alpha)$ increases. In other words,

$$
\mathrm{D}(\mathrm{w}, \alpha)>\mathrm{D}(\mathrm{w}, 1), \text { for all } \alpha<1
$$

Now we are in a position to define an equilibrium for this model. The equilibrium is defined for a given wage $\mathrm{w}$. We do not as yet question where the w comes from. In fact, for now, we deliberately treat the wage as exogenous. This allows us to analyze the effect of legal minimum wages. Later we show how this model can be integrated with endogenous wage rigidity.

Given a wage w, we shall describe an equilibrium to be a probability, $\mathrm{p}$, of a worker finding work, where

$$
\mathrm{p}^{*}=\min \left\{\frac{\mathrm{D}\left(\mathrm{w}, \alpha\left(\mathrm{w}, \mathrm{p}^{*}\right)\right)}{\mathrm{hs}\left(\mathrm{w}, \mathrm{p}^{*}\right)}, 1\right\}
$$

This is a standard definition of equilibrium best understood in terms of rational expectations. Given $w$, if we can find a $\mathrm{p}^{*}$ which prompts a demand $\left[\mathrm{D}\left(\mathrm{w}, \alpha\left(\mathrm{w}, \mathrm{p}^{*}\right)\right)\right]$ and a supply $\left[\mathrm{hs}\left(\mathrm{w}, \mathrm{p}^{*}\right)\right]$ such that the probability of finding work $\left[\min \left\{\mathrm{D}\left(\mathrm{w}, \alpha\left(\mathrm{w}, \mathrm{p}^{*}\right)\right) / \mathrm{hs}\left(\mathrm{w}, \mathrm{p}^{*}\right), 1\right\}\right]$ turns out to $\mathrm{be} \mathrm{p}^{*}$, then we have an equilibrium.

This is actually a rather interesting equilibrium which captures several features of reality. This can be seen from a diagrammatic illustration of an equilibrium shown in Figure 4. 
Suppose at $\hat{w}, p=\frac{\hat{w} D}{\hat{w} S}$. Then a wage of $\hat{w}$ with the firm(s) demanding D workers, and households supplying $\mathrm{S}$ workers is an equilibrium. It is interesting to note that actual employment, $\mathrm{E}$, will be less than $\mathrm{S}$ and $\mathrm{D}$. This is quite a realistic characterization of labor markets. Despite there being an excess supply of labor, firms find that all job offers are not accepted. Employment is less than the aggregate demand for labor expressed in the market.

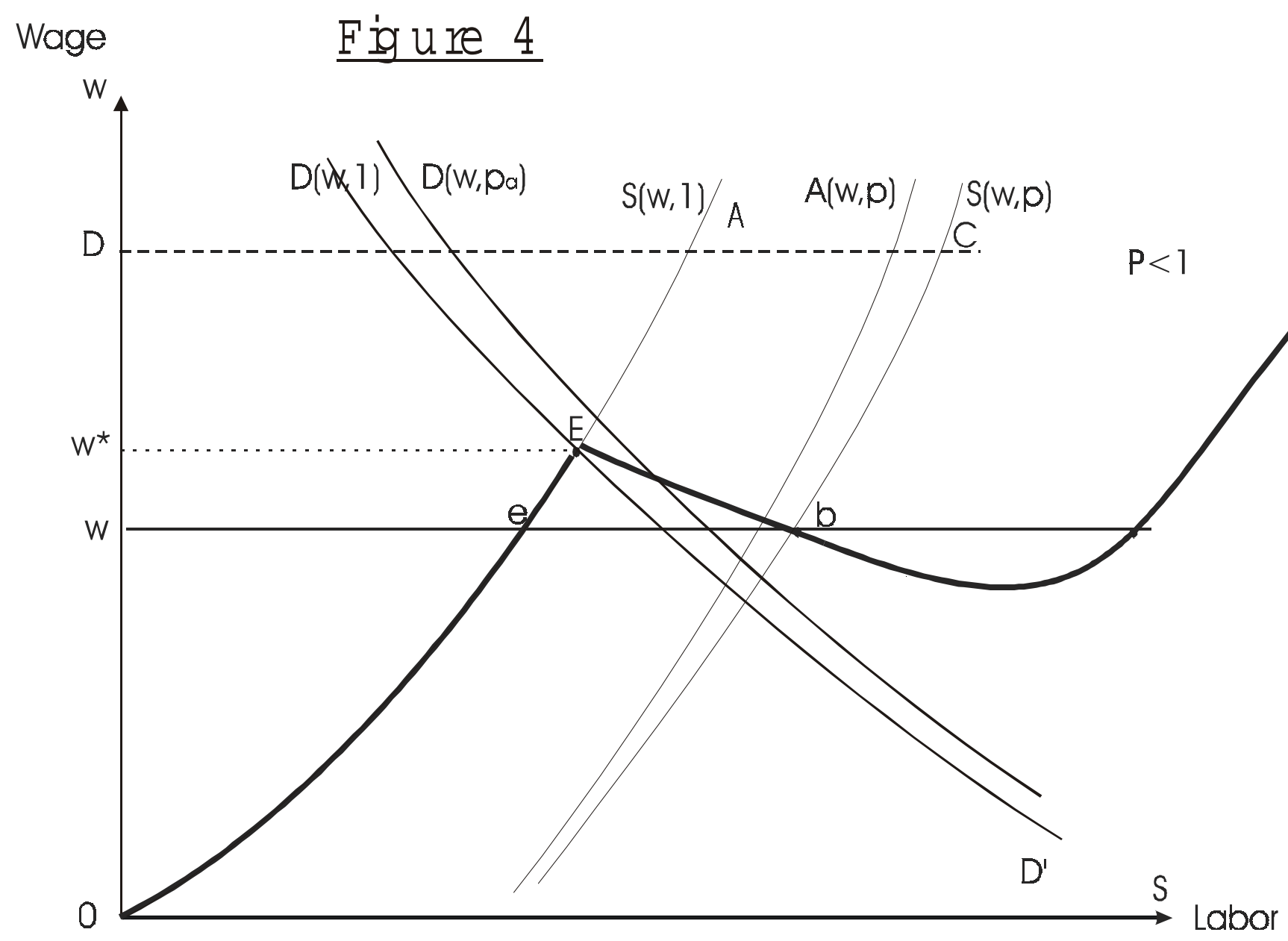

The standard neoclassical equilibrium with no unemployment is of course an equilibrium here. This happens at wage equal to $\tilde{\mathrm{w}}$. If wages are flexible this is the outcome that we would expect to see. If a minimum wage legislation fixes wage 
exogenously we will see excess supply of labor. As we already know from the previous section, this can happen even if the minimum wage is set below $\tilde{\mathrm{w}}$. Of course, even with wages legally free, we may have endogenous wage rigidities, caused for instance by standard efficiency wage arguments. This will be discussed later.

Now with the general framework specified, we shall consider different classes of special cases and study some of the situations that can arise within the context of this general model.

We shall first isolate a class of models where the added worker effect is invariably present. A sufficient condition for this is where (i) d is so high that a worker who applies for work never turns down an offer. This happens if $d \geq c$. Given this condition, an increase in aggregate unemployment (i.e. a decrease in p) invariably leads households to supply more labor.

Theorem 1 Given $d \geq c,[\hat{p}<\tilde{p}] \rightarrow[S(w, \hat{p})>S(w, \tilde{p})]$, for all $w>0$.

Proof. Given $d \geq c$ it is easy to see that whoever seeks work and finds it will take it.

Hence, (3) reduces to

$$
\mathrm{W}(\mathrm{n}, \mathrm{p}, \mathrm{w})=\sum_{\mathrm{k}=0}^{\mathrm{n}} \pi(\mathrm{k} \mid \mathrm{n}, \mathrm{p})[\mathrm{V}(\mathrm{kw})-\mathrm{kc}]-\theta \mathrm{n}
$$

Note that we would have proved this Theorem if we can show the following: If

$$
\mathrm{W}(\mathrm{n}, \tilde{\mathrm{p}}, \mathrm{w})<\mathrm{W}(\mathrm{n}+1, \tilde{\mathrm{p}}, \mathrm{w})
$$

then

$$
\mathrm{W}(\mathrm{n}, \hat{\mathrm{p}}, \mathrm{w})<\mathrm{W}(\mathrm{n}+1, \hat{\mathrm{p}}, \mathrm{w}), \text { for all } \hat{\mathrm{p}}<\tilde{\mathrm{p}}
$$


So in the remainder of the proof, we show that (8) implies (9). Note that this being true is independent of the value of $\theta$. So in the remainder of the proof we assume $\theta=0$. The proof is developed in four steps.

Step 1: If $n+1$ persons from a household apply for jobs, we could think of the household's expected welfare to be a weighted average of two possible events; one where person 1 does not find a job (probability $1-\mathrm{p}$ ) and one where he does find a job (probability p). Hence, we may write

$$
\left.\mathrm{W}(\mathrm{n}+1, \mathrm{p}, \mathrm{w})=(1-\mathrm{p}) \mathrm{W}(\mathrm{n}, \mathrm{p}, \mathrm{w})+\mathrm{p}\left[\sum_{\mathrm{k}=0}^{\mathrm{n}} \pi(\mathrm{k} \mid \mathrm{n}, \mathrm{p}) \mathrm{V}((\mathrm{k}+1) \mathrm{w})\right)-\mathrm{npc}-\mathrm{c}\right]
$$

Hence,

$$
\begin{aligned}
\mathrm{W}(\mathrm{n}+1, \mathrm{p}, \mathrm{w})-\mathrm{W}(\mathrm{n}, \mathrm{p}, \mathrm{w})= & \mathrm{p}\left[\sum_{\mathrm{k}=0}^{\mathrm{n}}(\pi(\mathrm{k} \mid \mathrm{n}, \mathrm{p}) \mathrm{V}((\mathrm{k}+1) \mathrm{w}))-\mathrm{npc}-\mathrm{c}-\mathrm{W}(\mathrm{n}, \mathrm{p}, \mathrm{w})\right] \\
= & \mathrm{p}\left[\sum_{\mathrm{k}=0}^{\mathrm{n}} \pi(\mathrm{k} \mid \mathrm{n}, \mathrm{p})(\mathrm{V}((\mathrm{k}+1) \mathrm{w})-\mathrm{V}(\mathrm{kw}))-\mathrm{c}\right], \\
& \text { by the definition of } \mathrm{W}(\mathrm{n}, \mathrm{p}, \mathrm{w}) .
\end{aligned}
$$

Hence, by defining $\mathrm{Z}(\mathrm{k}) \equiv \mathrm{V}((\mathrm{k}+1) \mathrm{w})-\mathrm{V}(\mathrm{kw})$, we have

$$
\mathrm{W}(\mathrm{n}+1, \mathrm{p}, \mathrm{w})-\mathrm{W}(\mathrm{n}, \mathrm{p}, \mathrm{w})=\mathrm{p}\left[\sum_{\mathrm{k}=0}^{\mathrm{n}} \pi(\mathrm{k} \mid \mathrm{n}, \mathrm{p}) \mathrm{Z}(\mathrm{k})-\mathrm{c}\right]
$$

Step 2: It will now be shown that as $\mathrm{p}$ drops from $\tilde{\mathrm{p}}$ to $\hat{\mathrm{p}}$, there exists $\mathrm{k}^{*}$, such that, for all $\mathrm{k} \leq \mathrm{k}^{*}, \pi(\mathrm{k} \mid \mathrm{n}, \hat{\mathrm{p}}) \geq \pi(\mathrm{k} \mid \mathrm{n}, \tilde{\mathrm{p}})$ and, for all $\mathrm{k}>\mathrm{k}^{*}, \pi(\mathrm{k} \mid \mathrm{n}, \hat{\mathrm{p}})<\pi(\mathrm{k} \mid \mathrm{n}, \tilde{\mathrm{p}})$

To see this, recall that

$$
\pi(k \mid n, p)=\left[\frac{n !}{(n-k) ! k !}\right] p^{k}(1-p)^{n-k}
$$

Hence, $\quad \pi(\mathrm{k} \mid \mathrm{n}, \hat{\mathrm{p}}) \geq \pi(\mathrm{k} \mid \mathrm{n}, \tilde{\mathrm{p}})$, if and only if 


$$
\hat{\mathrm{p}}^{\mathrm{k}}(1-\hat{\mathrm{p}})^{\mathrm{n}-\mathrm{k}} \geq \tilde{\mathrm{p}}^{\mathrm{k}}(1-\tilde{\mathrm{p}})^{\mathrm{n}-\mathrm{k}}
$$

or

$$
\left[\frac{\hat{\mathrm{p}}}{\tilde{\mathrm{p}}}\right]^{\mathrm{k}}\left[\frac{1-\tilde{\mathrm{p}}}{1-\hat{\mathrm{p}}}\right]^{\mathrm{k}} \geq\left[\frac{1-\tilde{\mathrm{p}}}{1-\hat{\mathrm{p}}}\right]^{\mathrm{n}}
$$

Given that $\hat{\mathrm{p}}<\tilde{\mathrm{p}}$, if the above inequality, (12), holds for some $\mathrm{k}^{\prime}$, then it must hold for all $\mathrm{k} \leq \mathrm{k}^{\prime}$; and if the above inequality is invalid for some $\mathrm{k}^{\prime}$, then it must be invalid for all $k>k^{\prime}$. This completes the proof of the claim made at the start of Step 2.

Step 3: This step consists of showing that as $p$ falls from $\tilde{p}$ to $\hat{p}, \sum_{k=0}^{n} \pi(k \mid n, p) Z(k)$ must rise.

Note that concavity of the household utility from consumption implies that

$$
\mathrm{Z}(0)>\mathrm{Z}(1)>\ldots>\mathrm{Z}(\mathrm{n})
$$

Intuitively, the proof of the claim being made in this step is immediate. Note that $\sum_{\mathrm{k}=0}^{\mathrm{n}} \pi(\mathrm{k} \mid \mathrm{n}, \mathrm{p}) \mathrm{Z}(\mathrm{k})$ is simply a weighted average of $\mathrm{Z}(0), \mathrm{Z}(1), \ldots, \mathrm{Z}(\mathrm{n})$. As $\mathrm{p}$ falls, we know from Step 2 that the weights shift towards the higher-valued elements, so the value of the sum must rise.

To see this formally, as $\mathrm{p}$ falls from $\tilde{\mathrm{p}}$ to $\hat{\mathrm{p}}$, let $\mathrm{k}^{*}$ be the critical integer identified in Step 2. Clearly, 


$$
\begin{aligned}
& \sum_{\mathrm{k}=0}^{\mathrm{n}} \pi(\mathrm{k} \mid \mathrm{n}, \hat{\mathrm{p}}) \mathrm{Z}(\mathrm{k})-\sum_{\mathrm{k}=0}^{\mathrm{n}} \pi(\mathrm{k} \mid \mathrm{n}, \tilde{\mathrm{p}}) \mathrm{Z}(\mathrm{k}) \\
& =\sum_{\mathrm{k}=0}^{\mathrm{k}^{*}}[\pi(\mathrm{k} \mid \mathrm{n}, \hat{\mathrm{p}})-\pi(\mathrm{k} \mid \mathrm{n}, \tilde{\mathrm{p}})] \mathrm{Z}(\mathrm{k})-\sum_{\mathrm{k}=\mathrm{k}^{*}+1}^{\mathrm{n}}[\pi(\mathrm{k} \mid \mathrm{n}, \tilde{\mathrm{p}})-\pi(\mathrm{k} \mid \mathrm{n}, \hat{\mathrm{p}})] \mathrm{Z}(\mathrm{k}) \\
& >\sum_{\mathrm{k}=0}^{\mathrm{k}^{*}}[\pi(\mathrm{k} \mid \mathrm{n}, \hat{\mathrm{p}})-\pi(\mathrm{k} \mid \mathrm{n}, \tilde{\mathrm{p}})] \mathrm{Z}\left(\mathrm{k}^{*}\right)-\sum_{\mathrm{k}=\mathrm{k}^{*}+1}^{\mathrm{n}}[\pi(\mathrm{k} \mid \mathrm{n}, \tilde{\mathrm{p}})-\pi(\mathrm{k} \mid \mathrm{n}, \hat{\mathrm{p}})] \mathrm{Z}\left(\mathrm{k}^{*}\right)
\end{aligned}
$$

by the definition of $\mathrm{k}^{*}$ and (13).

$=\left(\sum_{\mathrm{k}=0}^{\mathrm{k}^{*}}[\pi(\mathrm{k} \mid \mathrm{n}, \hat{\mathrm{p}})-\pi(\mathrm{k} \mid \mathrm{n}, \tilde{\mathrm{p}})]-\sum_{\mathrm{k}=\mathrm{k}^{*}+1}^{\mathrm{n}}[\pi(\mathrm{k} \mid \mathrm{n}, \tilde{\mathrm{p}})-\pi(\mathrm{k} \mid \mathrm{n}, \hat{\mathrm{p}})]\right) \mathrm{Z}\left(\mathrm{k}^{*}\right)=0$, since the probabilities must add up to 1 .

Step 4: An immediate implication of Step 3 is that if $\tilde{\mathrm{p}}\left[\sum_{\mathrm{k}=0}^{\mathrm{n}} \pi(\mathrm{k} \mid \mathrm{n}, \tilde{\mathrm{p}}) \mathrm{Z}(\mathrm{k})-\mathrm{c}\right]>0$ and $\tilde{\mathrm{p}}<\tilde{\mathrm{p}}$, then $\hat{\mathrm{p}}\left[\sum_{\mathrm{k}=0}^{\mathrm{n}} \pi(\mathrm{k} \mid \mathrm{n}, \hat{\mathrm{p}}) \mathrm{Z}(\mathrm{k})-\mathrm{c}\right]>0$. In the light of (11) this completes the proof. $\mid$ What this theorem asserts is that as the labor market worsens, in the sense of a decrease in the probability p of finding a job, households will respond by supplying more labor. This justifies our Figures 1 and 2 where $p^{\prime \prime}<p^{\prime}<1$. Note that in drawing these figures we ignore the fact that in our mathematical model labor supply takes only integer values.

Observe that in Figure 2 the actual aggregate supply curve is multi-valued for some wages, for instance $\hat{\mathrm{w}}$. This happens because the actual supply curve rises up to point E, drops down and then rises again. Since much of the interesting analysis arises because of the multi-valuedness of the supply curve, the question must arise whether this can actually happen or whether Figure 2 is a figment of pure geometric imagination. The answer is that this can not only happen but is eminently plausible.

In Figure 2 let us use E' to label the point (not shown in the figure) horizontally to the right of $\mathrm{E}$ and on the quasi-supply curve $\mathrm{S}\left(\mathrm{w}, \mathrm{p}^{\prime}\right)$. It is easy to conceive of a model 
where households respond to a small fall in $\mathrm{p}$ from 1 with a large increased labor supply. So let us suppose that, in Figure 2, p - p' is very small. In particular, let p' be greater than $\mathrm{w}^{*} \mathrm{E} / \mathrm{w}^{*} \mathrm{E}^{\prime}$. Then, given that the demand curve is downward sloping and assuming that the quasi-supply curve is upward sloping, it follows that the only point satisfying rational expectations on the quasi-supply curve $S\left(w, p^{\prime}\right)$ must be below $E^{\prime}$. Hence, the actual supply curve turns downwards at E, thereby assuring multi-valuedness.

It is worth noting that the above claim does not hinge on the assumption $\mathrm{d} \geq \mathrm{c}$. Consider the case where $\mathrm{d}=0$ and $\mathrm{c}>0$. Now both added worker and discouragement effects co-exist. But even in this case, as labor market conditions worsen, in the sense of $\mathrm{p}$ falling, households first respond by supplying more labor when the fixed cost of searching and unemployment are relatively small.

It is now interesting to see what the full labor market equilibrium looks like in this special case where $\mathrm{d} \geq \mathrm{c}$. Given this condition, workers who apply for work will invariably accept an offer (at the prevailing market wage). That being so $\alpha(w, p)=1$, for all $\mathrm{w}$ and $\mathrm{p}$. Hence in this special case the aggregate demand for labor curve is given by $\mathrm{D}(\mathrm{w}, 1)$ no matter what the value of $\mathrm{p}$. For convenience we write $\mathrm{D}(\mathrm{w}, 1) \equiv \mathrm{D}(\mathrm{w})$. Basically now firms will not "over-recruit" workers in anticipation of offers being turned down. In the class of situations described by $d \geq c$, we shall say that a wage $w$ and a labor supply z constitute an 'equilibrium' if $\mathrm{D}(\mathrm{w})=\mathrm{S}(\mathrm{w}, 1)$ and $\mathrm{z}=\mathrm{S}(\mathrm{w}, 1)$.

Given a model as just described plus a minimum wage law, the idea of an equilibrium becomes more complicated. If the minimum $w$ age is set at $\hat{\mathrm{w}}$, we shall say that a wage $\mathrm{w}$ and labor supply z constitute an 'equilibrium' if (i) $\mathrm{w}>\hat{\mathrm{W}}$ and 
$\mathrm{D}(\mathrm{w})=\mathrm{S}(\mathrm{w}, 1)=\mathrm{z}$; or (ii) $\mathrm{w}=\tilde{\mathrm{w}}$ and there exists $\mathrm{p}$ such that $\mathrm{D}(\mathrm{w}) \leq \mathrm{S}(\mathrm{w}, \mathrm{p})=\mathrm{z}$, and $\frac{\mathrm{D}(\mathrm{w})}{\mathrm{S}(\mathrm{w}, \mathrm{p})}=\mathrm{p}$.

In brief, if the equilibrium wage is above the legal minimum wage, the demand for labor must be equal to the supply of labor, and if the equilibrium wage is equal to the legal minimum wage, then supply of labor can exceed demand. In each case, we also have to make sure that the rational expectations properties are fulfilled.

The paradoxical result discussed in Section 3 about how the imposition of a legal minimum wage below the free market wage can create a new equilibrium wage below the free market wage is now evident.

\section{WAGE RIGIDITIES AND THE EFFICIENCY WAGE}

In this section we explore some of the informal dynamics of wages and unemployment suggested by our model, given exogenously fixed wages (5.1) and then see how we can integrate a model of endogenous wage rigidity with our model (5.2). We continue to work here with the special case where laborers, who register at the employment exchange for work, accept offers as long as these pay the going wage.

\subsection{Formation of Expectations and Price Rigidities}

As a first step let us consider the way expectations of the employment rate $\mathrm{p}^{\mathrm{e}}$ influence the actual employment rate $\mathrm{p}$, assuming that wage is completely rigid. Let us for simplicity suppose that the demand curve is a straight line $\mathrm{DD}_{0}$ as shown in Figure 5, and that wage is rigid at $w^{*}$. To study the dynamics of expectations, assume that because of some minor disturbance the labor market is out of equilibrium and currently at point 1 
in Figure 5. This could be for instance because the demand curve has recently moved left to $\mathrm{DD}_{0}$. This will mean that people will revise their expectation of $\mathrm{p}$.

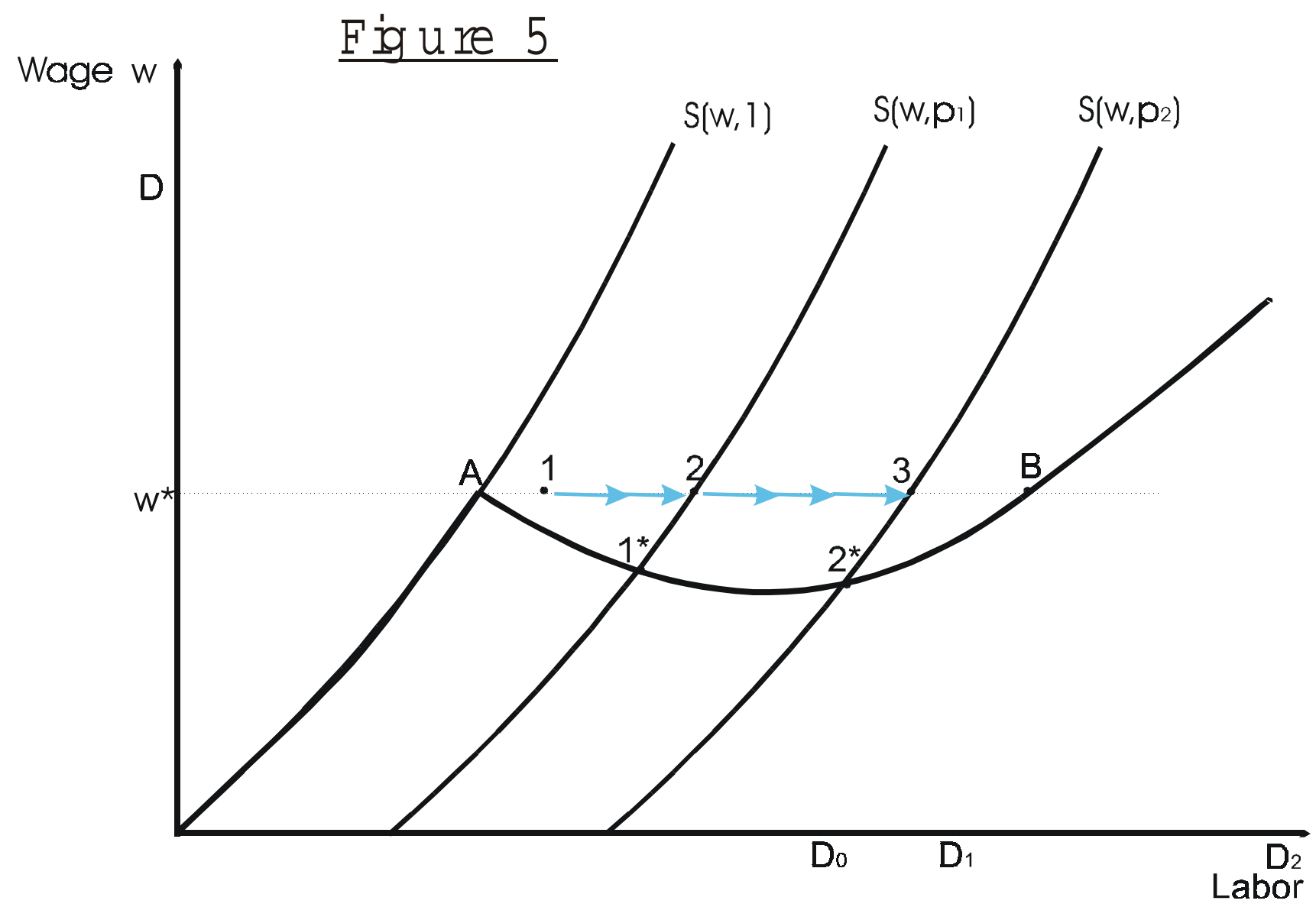

To see what the revised expectation will be, draw a ray from $\mathrm{D}$ through point 1 .

Let $1^{*}$ be the point where it intersects the actual aggregate supply curve and let $S\left(w, p_{1}\right)$ be the quasi supply through this point. Clearly at point 1 the revised expectation of the employment rate will be $\mathrm{p}_{1}$. Hence, (with rigid wage) the labor supply will increase up to point 2. But at point 2 the employment rate will need to be revised again. And, by a similar reasoning, the revised rate will be $\mathrm{p}_{2}$ and there will again be an additional supply response moving the labor market towards point 3. And the process continues, like Achilles and the tortoise, coming to a halt only at B. In brief, if the economy started at 
point A in Figure 6, wages were fully fixed, and there was a slight shock causing a small unemployment to appear, the market would end up at point B.

Now we are in a position to investigate the movement in wage and employment when wage are partially rigid. Suppose $\mathrm{DD}_{0}$ in Figure 5 does represent the demand for labor and that the economy is at the full employment equilibrium A. The wage is $\mathrm{w}^{*}$ and demand equals supply. Now suppose there is a small drop in the demand that decreases p. This drop is likely to have two types of effect. On the one hand, if it results in a decrease in the expected employment rate $\mathrm{p}^{\mathrm{e}}$, households will respond by increasing their labor supply. This in turn causes the actual employment rate to decrease even more. On the other hand, an excess supply of labor puts a downwards pressure on wage, which in turn results in an increase in the labor demand and a decrease in the labor supply, pushing up the actual employment rate. The net effect is likely to depend on the speed of adaptation of both the wage and the expectations. At the extreme, if there is no rigidity in the wage and expectations are slow to adapt, the drop in the wage will instantaneously correct for the small drop in the labor demand and the added worker effect will not occur. At the other extreme, if wages are perfectly rigid downwards, the cumulative effect of worsening expectations and increasing unemployment will result in the economy shifting from A to point B in Figures 5 and 6. The most likely effect will be in between these two cases. The small shock in the demand first increases the unemployment and this even more as expectation worsen, but at some point, the wage will fall reversing the effect, the employment rate increases improving the expectations, and the economy comes back to its initial equilibrium A, all described by the loop in Figure 6. 


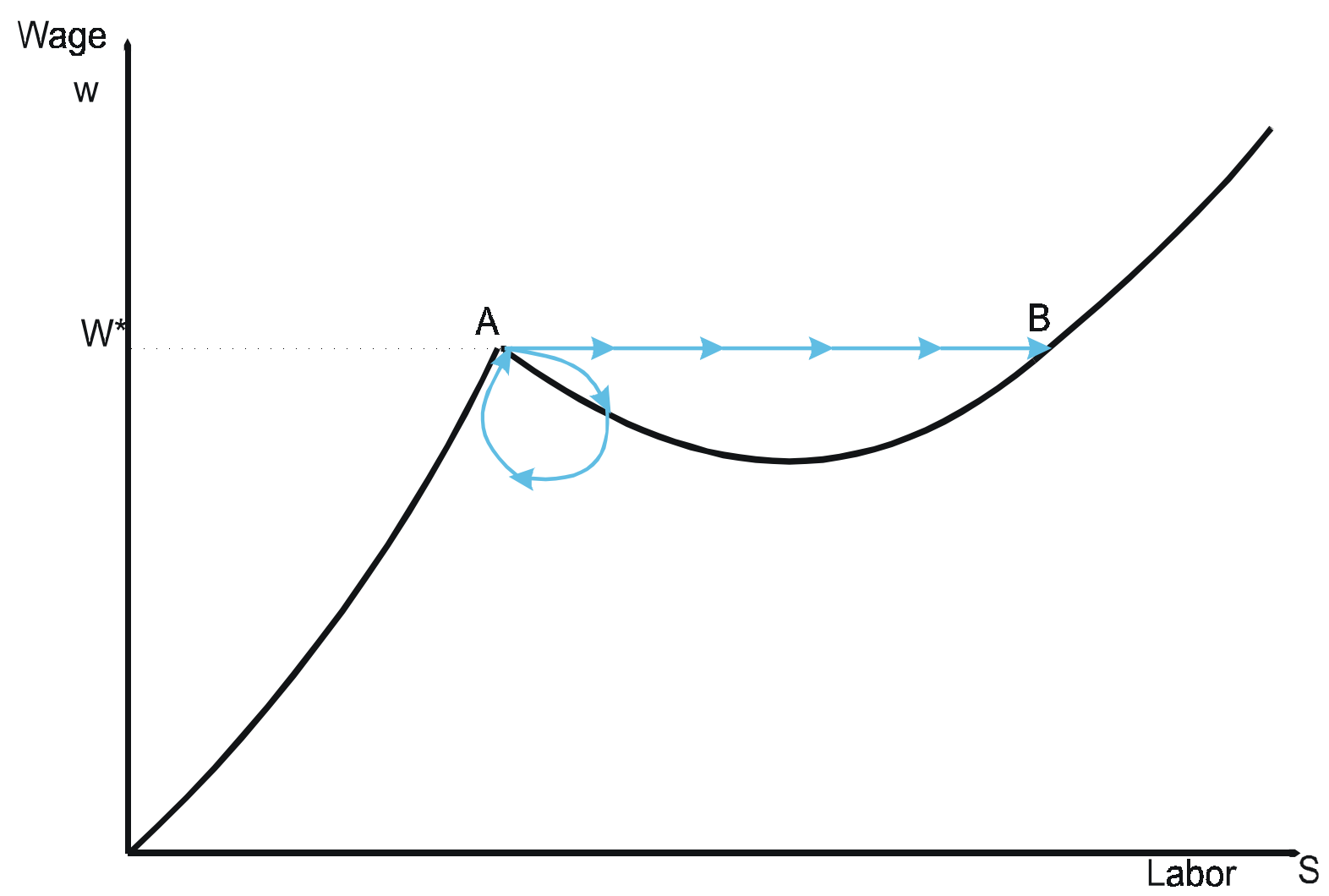

\subsection{Efficiency Wage}

The above model has interesting implications when combined with standard theories of efficiency wage. An efficiency wage is a wage rate that employers prefer to pay even when they have the option of paying a lower wage and finding enough workers willing to work for them (see Leibenstein, 1957; Stiglitz, 1976; Schlicht, 1978, to cite a random few from a large literature). In the efficiency wage theories in which the value of the efficiency wage depends on the level of unemployment (for instance, Stiglitz, 1974; Shapiro and Stiglitz, 1984; Fehr, 1986) the story can be special. When a larger unemployment rate acts as a disciplining device, the efficiency wage paid to the workers is a decreasing function of the unemployment rate. If this effect is strong there will be a single equilibrium. Multiple equilibria along with some interesting implications arise if 
this effect is weak and in other kinds of efficiency wage models. We shall here illustrate this with a model in which the wage rigidity is prompted by the fact that a higher consumption can enhance a worker's productivity.

Assume $J$ identical firms endowed with a production function $f(\lambda)$ where $\lambda$ is the labor input of the firm and $f(0)=0, f^{\prime}(\lambda)>0$, and $f^{\prime \prime}(\lambda) \leq 0$. A firm's labor input depends not only on the number of workers it employs but also on the efficiency of their work. Consider, for instance a nutrition-efficiency wage model in which an individual's work capacity depends on his or her consumption. To abstract from many complications, which although interesting in themselves are beyond the purview of this paper, we make the following assumptions: the number of households and firms are large such that the probability that two members of the same household receive offers in the same firm is negligible; employers do not know how many other members of a worker's household are employed (this could be because it is too costly to collect the information), and $\mathrm{e}(\mathrm{Y})$ is the efficiency of a worker in a household with aggregate income $\mathrm{Y}$ where $\mathrm{e}(\mathrm{Y})$ is increasing in $\mathrm{Y}$ and convex at very low values of $\mathrm{Y}$ and then concave. ${ }^{\mathrm{B}}$ firm $\mathrm{j}$ 's problem is therefore to choose the number of workers $\mathrm{n}$ and a wage $\mathrm{w}$ in order to

$$
\underset{n, w}{\operatorname{Max}} \operatorname{Ef}\left(n e\left(w+k w_{-j}\right)\right)-n w, \text { subject to } w \leq w^{*}
$$

where $\mathrm{w}^{*}$ is the market clearing wage, $\mathrm{w}_{-\mathrm{j}}$ is the wage paid by other firms and where the expectation $\mathrm{E}$ is on the number $\mathrm{k}$ of other members of a worker's household that are employed (and this implicitly depends on p).

Let $\hat{\mathrm{n}}\left(\mathrm{w}_{-\mathrm{j}}, \mathrm{p}\right)$ and $\hat{\mathrm{w}}\left(\mathrm{w}_{-\mathrm{j}}, \mathrm{p}\right)$ be the solution to the above maximization problem solved by ignoring the constraint $\mathrm{w} \geq \mathrm{w}^{*}$.

Define w(p) to be a wage w which solves the equation 


$$
\hat{\mathrm{w}}(\mathrm{w}, \mathrm{p})=\mathrm{w} .
$$

If $\mathrm{w}(1) \leq \mathrm{w}^{*}$, the market-clearing wage $\mathrm{w}^{*}$ and full-employment characterize an equilibrium. If the labor supply curve is as in Figure 2, then there may be another equilibrium in which firms pay a wage of $w(p)$ and $p$ is such that $\mathrm{p}=\mathrm{J} \hat{\mathrm{n}}(\mathrm{w}(\mathrm{p}), \mathrm{p}) / \mathrm{S}(\mathrm{w}(\mathrm{p}), \mathrm{p})<1$.

If $\mathrm{w}(1)>\mathrm{w}^{*}$, then there is an equilibrium with open unemployment and the wage is rigid at $\mathrm{w}(1)$. The magnitude of the unemployment may however be larger than what would prevail in the standard efficiency wage model. This is a consequence of the added-worker effect.

\section{EXTENSIONS}

In the remainder of this paper, we explore different policy implications of our model, and show why the discouragement effect may have been overestimated in the empirical literature.

\subsection{Unemployment Benefits}

Turning now to some questions of policy, we shall in this section study the effect of unemployment benefits on the kind of equilibrium obtained in the labor market.

Suppose in Figure 2 the wage has a floor at $\hat{w}$. This can be because there is a minimum wage law or because $\hat{w}$ happens to be the efficiency wage. The exact explanation does not matter for our purpose here. There are then three possible equilibria--at points $\mathrm{E}, \mathrm{b}$ and $\mathrm{z}$. Let us check on the welfare properties of these equilibria. Clearly, given that this is a competitive market, the equilibrium at $\mathrm{E}$ is the most efficient. 
At $\mathrm{b}$ and $\mathrm{z}$ there is greater output but this is caused by workers working excessively, for fear of unemployment. The household's welfare is the highest at E, since there is full employment and the wage is higher. Between the two other equiulibria, our conjecture is that $\mathrm{b}$ dominates $\mathrm{z} .^{\mathrm{b}}$ Output and employment is the same at $\mathrm{b}$ and $\mathrm{z}$, but there is more unemployment at z. As we switch to a more general formulation, where costs of effort vary across individuals, $\mathrm{z}$ becomes even more welfare dominated by $\mathrm{b}$. The reason is that more people supply labor at $\mathrm{z}$ than at $\mathrm{b}$. This means that, at $\mathrm{z}$, workers whose effort is more costly supply labor. So a random selection of workers at $\mathrm{z}$ will contain more of these inefficient (in the sense of high cost) workers than a random selection at $b$. So the expected effort cost at $\mathrm{z}$ is more and so this accentuates the welfare difference between both equilibria. Since $\mathrm{z}$ is the stable equilibrium and $\mathrm{b}$ is unstable, this is a worrying consequence of the added worker effect. In the absence of the added worker effect the equilibrium would move to $\mathrm{E}$. This raises the question whether we can devise policy which counteracts the tendency of workers to oversupply labor.

Since the oversupply is a consequence of the workers fearing that their household will be left without adequate employed members, any policy that combats this risk should improve matters. ${ }^{7}$ An obvious candidate is a safety net for the unemployment. We shall here study a safety net at the level of the household, since it is the household-level decision making which is the source of the problem. If this is properly designed the safety net may seldom have to be used. It is its mere presence that can change household behavior favorably. So it need not cause any fiscal strain.

To see formally how this works, suppose that the government guarantees an income of $\mathrm{G}$ for each household. So any household whose income drops below $\mathrm{G}$ is 
given enough unemployment benefit for the household to consume G. If we use $\tilde{\mathrm{W}}$ to denote a household's expected welfare, then following a notation similar to that used in Section 4 , and staying for simplicity with the special case, were $\mathrm{d} \geq \mathrm{c}$, we may write

$$
\tilde{\mathrm{W}}(\mathrm{n}, \mathrm{p}, \mathrm{w}, \mathrm{G})=\sum_{\mathrm{k}=0}^{\mathrm{n}} \pi(\mathrm{k} \mid \mathrm{n}, \mathrm{p}) \mathrm{V}(\max \{\mathrm{kw}, \mathrm{G}\})-\mathrm{npc}
$$

Given $\mathrm{p}, \mathrm{w}, \mathrm{G}$ the household's total supply of labor $\widetilde{\mathrm{s}}$ is defined as follows:

$$
\widetilde{\mathrm{s}}(\mathrm{p}, \mathrm{w}, \mathrm{G})=\arg \max _{\mathrm{n}} \tilde{\mathrm{W}}(\mathrm{n}, \mathrm{p}, \mathrm{w}, \mathrm{G})
$$

The question that we want to investigate is the effect of $\mathrm{G}$ on the supply of labor.

The next theorem sums this up.

Theorem 2: As G increases, $\widetilde{s}(\mathrm{p}, \mathrm{w}, \mathrm{G})$ (weakly) decreases.

Proof: Following a strategy similar to the one used to prove Theorem 1, note that

$$
\tilde{\mathrm{W}}(\mathrm{n}+1, \mathrm{p}, \mathrm{w}, \mathrm{G})=(1-\mathrm{p}) \tilde{\mathrm{W}}(\mathrm{n}, \mathrm{p}, \mathrm{w}, \mathrm{G})+\mathrm{p}\left[\sum_{\mathrm{k}=0}^{\mathrm{n}} \pi(\mathrm{k} \mid \mathrm{n}, \mathrm{p}) \mathrm{V}(\max \{\mathrm{G},(\mathrm{k}+1) \mathrm{w}\})-\mathrm{npc}-\mathrm{c}\right]
$$

Hence

$$
\tilde{\mathrm{W}}(\mathrm{n}+1, \mathrm{p}, \mathrm{w}, \mathrm{G})-\tilde{\mathrm{W}}(\mathrm{n}, \mathrm{p}, \mathrm{w}, \mathrm{G})=\mathrm{p}\left[\sum_{\mathrm{k}=0}^{\mathrm{n}} \pi(\mathrm{k} \mid \mathrm{n}, \mathrm{p})(\mathrm{V}(\max \{\mathrm{G},(\mathrm{k}+1) \mathrm{w}\})-\mathrm{V}(\max \{\mathrm{G}, \mathrm{kw}\})-\mathrm{c}]\right.
$$

Define $\mathrm{k}(\mathrm{G})$ such that

$$
(k(G)+1) w>G \geq k(G) w
$$

If $w>0$, then $\mathrm{k}(\mathrm{G})$ is well defined. Using this definition, we have

$$
\begin{aligned}
& \tilde{\mathrm{W}}(\mathrm{n}+1, \mathrm{p}, \mathrm{w}, \mathrm{G})-\tilde{\mathrm{W}}(\mathrm{n}, \mathrm{p}, \mathrm{w}, \mathrm{G})=\mathrm{p}[\pi(\mathrm{k}(\mathrm{G}) \mid \mathrm{n}, \mathrm{p})(\mathrm{V}((\mathrm{k}(\mathrm{G})+1) \mathrm{w})-\mathrm{V}(\mathrm{G})) \\
& \left.+\sum_{\mathrm{k}=\mathrm{k}(\mathrm{G})+1}^{\mathrm{n}} \pi(\mathrm{k} \mid \mathrm{n}, \mathrm{p})[\mathrm{V}((\mathrm{k}+1) \mathrm{w})-\mathrm{V}(\mathrm{kw})]-\mathrm{c}\right]
\end{aligned}
$$


Suppose, first, that households supply positive amounts of labor. It is now easy to see that, if $\tilde{\mathrm{W}}(\mathrm{n}+1, \mathrm{p}, \mathrm{w}, \mathrm{G})-\tilde{\mathrm{W}}(\mathrm{n}, \mathrm{p}, \mathrm{w}, \mathrm{G}) \geq 0$ and $\mathrm{G}^{\prime} \leq \mathrm{G}$, then $\tilde{\mathrm{W}}\left(\mathrm{n}+1, \mathrm{p}, \mathrm{w}, \mathrm{G}^{\prime}\right)$

$-\tilde{\mathrm{W}}\left(\mathrm{n}, \mathrm{p}, \mathrm{w}, \mathrm{G}^{\prime}\right) \geq 0$.

To see this consider two cases:

(i) $\quad \mathrm{G}^{\prime} \geq \mathrm{k}(\mathrm{G}) \mathrm{w}$, and

(ii) $\quad \mathrm{G}^{\prime}<\mathrm{k}(\mathrm{G}) \mathrm{w}$

If (i), a fall in $\mathrm{G}$ to $\mathrm{G}^{\prime}$, leaves $\mathrm{k}(\mathrm{G})$ unchanged and increases $\mathrm{V}((\mathrm{k}(\mathrm{G})+1) \mathrm{w})-$

$\mathrm{V}(\mathrm{G})$. It follows that $\tilde{\mathrm{W}}(\mathrm{n}+1, \mathrm{p}, \mathrm{w}, \mathrm{G})-\tilde{\mathrm{W}}(\mathrm{n}, \mathrm{p}, \mathrm{w}, \mathrm{G})$ will rise; and so

$\tilde{\mathrm{W}}\left(\mathrm{n}+1, \mathrm{p}, \mathrm{w}, \mathrm{G}^{\prime}\right)-\tilde{\mathrm{W}}\left(\mathrm{n}, \mathrm{p}, \mathrm{w}, \mathrm{G}^{\prime}\right)>0$.

If (ii), a fall in $G$ to $G^{\prime}$ causes $k\left(G^{\prime}\right)$ to fall under $k(G)$, which again causes $\tilde{\mathrm{W}}(\mathrm{n}+1, \mathrm{p}, \mathrm{w}, \mathrm{G})-\tilde{\mathrm{W}}(\mathrm{n}, \mathrm{p}, \mathrm{w}, \mathrm{G})$ to rise.

Hence, in either case a rise in $\mathrm{G}$ causes quasi-supply to fall. I |

This proof was under the assumption that the households supply positive amounts of labor. Note that a household will cease to supply positive amounts of labor, if $\max _{\mathrm{n}} \tilde{\mathrm{W}}(\mathrm{n}, \mathrm{p}, \mathrm{w}, \mathrm{G}) \leq \mathrm{V}(\mathrm{G})$. Clearly, if $\mathrm{G}$ falls, the cut-off wage at which the household ceases to supply labor will fall.

Theorem 2 shows how unemployment benefit can dampen the added worker effect. It may be checked that an implication of this theorem is that as $\mathrm{G}$ increases, the aggregate supply curve moves (weakly) upwards. Hence, for each wage, w, the largest supply of labor satisfying rational expectations must fall. Hence, for a given minimum wage, a rise in $\mathrm{G}$ can cause unemployment to fall (with total employment remaining unchanged). Further it is easy to see that if $\mathrm{G}$ is kept at a small level, the quasi supply, 
when $\mathrm{p}$ is 1 , remains unaffected by the $\mathrm{G}$. That is, $\widetilde{\mathrm{s}}(1, \mathrm{w}, \mathrm{G})=\mathrm{s}(1, \mathrm{w})$. In other words there is no shirking of labor. So, interestingly, what this demonstrates is that unemployment benefits may be justified without having to invoke equity reasons, but purely on grounds of efficiency.

\subsection{Race, Gender and Unemployment}

A well-known fact for most economies is that unemployment rates vary across different categories of labor more than can be dismissed as natural stochastic variations. Thus, we often hear how Black unemployment exceeds White unemployment by a wide margin, or how unemployment for some caste groups in India is markedly larger than for others.

At first blush, it may appear that our model with its penchant for multiple equilibria may have an explanation for this. Indeed, it does offer an explanation but for reasons more roundabout than one may behave initially.

To see this, suppose first that employers are race-blind and caste-blind, that is, they select their workers randomly from among the unemployed without showing preference for any race or caste. Evidently, then the expected unemployment rates of Hispanics, Blacks and Whites, and any sub-category for that matter, must be the same. This fact remains unchanged even if it were the case that more Blacks supplied labor. In brief, this fact is independent of the supply responses of the different groups. If on the other hand, employers set themselves, or are given, quotas for different races and other 
sub-categories, or have diversity norms for the work-force, the unemployment rate can vary across different sub-groups. What is interesting is that this can happen even if employers follow diversity norms which are 'fair'.

To understand this, assume that a fraction $\beta$ of an economy's (working-age) population happens to be Black and 1- $\beta$ non-Black or, for simplicity, White. Let us suppose that the wage has a floor at $\hat{\mathrm{w}}$ below which it will not go. This can be because of a minimum wage law or because of efficiency wage arguments. Let us also suppose that $\hat{\mathrm{w}}$ is below the aggregate market-clearing wage $\mathrm{w}^{*}$. So the situation is akin to the one shown in Figure 2. Now assume that Blacks and Whites take their household labor decision not based on the aggregate employment rate $\mathrm{p}$ but race-specific employment rates, $\mathrm{p}_{\mathrm{b}}$ and $\mathrm{p}_{\mathrm{w}}$. Now it is entirely possible to have different racial unemployment rates despite the fact of the employer following the norm of employing workers so that a fraction $\beta$ of the workers are Blacks. The argument is easy to see. Suppose Blacks conjecture that $\mathrm{p}_{\mathrm{b}}$ is low, while Whites conjecture $\mathrm{p}_{\mathrm{w}}$ is high. Then this can create a relatively larger supply of black labor by bringing all black women into the labor force while white women stay at home, thereby fulfilling the initial conjectures.

Note finally that we assumed that the employers use a fair norm not because they actually do so, nor because that is necessary for our argument, but because that is the assumption under which our result is least expected. If employers use a biased norm, variations in race-specific unemployment rates are only to be expected.

It is interesting to note that the logic of sex-specific unemployment rates will have to be very different since most households consist of males and females, and so female labor supply will depend not just on $\mathrm{p}_{\mathrm{f}}$ (the employment rate of female) but also on $\mathrm{p}_{\mathrm{m}}$ 
(the male employment rate). And typically a larger male unemployment will cause a positive female labor supply response resulting in a larger female unemployment rate as well. Our model suggests that at a macro level male-female unemployment rates will tend to move together, though unemployment rates can vary markedly across races.

This leads us to an interesting micro question. How do unemployment rates within households and across gender vary? That is the subject matter of the next subsection.

\subsection{Discouragement Effect and Some Empirical Paradoxes}

A number of empirical studies of labor supply in the US have found the added worker effect to be feeble. ${ }^{-2}$ Other studies have pointed out that this effect may not be feeble but it's net effect is weak because it is offset by a comparable discouragement effect pushing in the opposite direction. 10 As we know from our general model in Section 4 the presence of search costs might explain a certain discouragement effect in the sense of a less active search. However, we are inclined to believe that in empirical studies the discouragement effect appears to be larger than it really is. We shall show this by assuming that there are no search costs and therefore, as in our Theorem 1 , there is no discouragement effect. Hence, from here on we assume $\mathrm{d} \geq \mathrm{c}$ and $\theta=0$. We will then show how with a small realistic modification of our model we can explain why it may be the case that the discouragement effect is overestimated.

The modification in question consists in allowing for the possibility that there are household-level factors which can influence a person's job prospect. This possibility is hinted at in a study by Layard, Barton and Zabalza (1980) and discussed more explicitly by Lundberg (1985). It seems quite reasonable to suppose that there are many influences 
which occur at the level of the households. The empirical evidence of "assorative mating" provide support for this assumption. In the U.S., in a typical household, both husband and wife are Black or both are White. Now if employers discriminate against Blacks, then either both will stand better chances on the market, or both will stand worse chances respectively. Likewise, if some locations provides better job opportunities, then again each member of one household may have better job prospects than each member of another household. The same is true if ones social network matters and if every husband and wife belong, or do not belong, to networks together.

To model this, let us assume that there are two types of households, 1 and 2. There are $h_{1}$ and $h_{2}$ households of each of these types and $h_{1}+h_{2}=h$. These two kinds of households are identical in every other way except that type 1 households are more likely to find jobs when there is unemployment. Let us model this by assuming that, when a type 1 individual (i.e. a person belonging to a household of type 1) applies for a job, he is $1+\gamma$ times as likely to get a job as a type 2 individual, where $\gamma>0$. It then follows that if $\mathrm{K}_{1}$ and $\mathrm{K}_{2}$ persons of types 1 and 2 supply their labor and there are $\mathrm{J}$ jobs going, then the probability of each type 2 person finding a job is given by (for simplicity, we assume that $\left.\mathrm{K}_{1}+\mathrm{K}_{2} \geq \mathrm{J}\right)$

$$
\mathrm{p}_{2}\left(\mathrm{~J}, \mathrm{~K}_{1}, \mathrm{~K}_{2}\right) \equiv \frac{\mathrm{J}}{(1+\gamma) \mathrm{K}_{1}+\mathrm{K}_{2}}
$$

and each of type 1 person being employed is given by

$$
\mathrm{p}_{1}\left(\mathrm{~J}, \mathrm{~K}_{1}, \mathrm{~K}_{2}\right) \equiv \frac{(1+\gamma) \mathrm{J}}{(1+\gamma) \mathrm{K}_{1}+\mathrm{K}_{2}}
$$

The lottery process which gives us these probabilities may be thought of as follows. When the employment exchange gets $K_{1}$ and $K_{2}$ job applications from types 1 
and 2, respectively, and has $\mathrm{J}$ jobs to allocate $\left(\mathrm{K}_{1}+\mathrm{K}_{2} \geq \mathrm{J}\right)$, earlier (that is in Sections 3

and 4), the employment exchange may have been thought of as allocating $\frac{\mathrm{K}_{1} \mathrm{~J}}{\mathrm{~K}_{1}+\mathrm{K}_{2}}$ jobs

to type 1 applicants and $\frac{\mathrm{K}_{2} \mathrm{~J}}{\mathrm{~K}_{1}+\mathrm{K}_{2}}$ to type 2 . Now it sets aside $\frac{(1+\gamma) \mathrm{K}_{1} \mathrm{~J}}{(1+\gamma) \mathrm{K}_{1}+\mathrm{K}_{2}}$ jobs for

type 1 applicants and $\frac{\mathrm{K}_{2} \mathrm{~J}}{(1+\gamma) \mathrm{K}_{1}+\mathrm{K}_{2}}$ for type 2, picking within each category by some unbiased lottery mechanism.

From here we can proceed along two alternative routes. First, we could assume that households are unaware of their differing probabilities of being employed and so both types use the aggregate employment rate as expected probability of finding jobs. Second, we could assume that households are more discerning and compute their own probability of being employed as $p_{1}$ and $p_{2}$ depending on whether they are of type 1 or type 2. Both routes lead to the same conclusion but we illustrate the argument by making the second assumption. Then, given $\mathrm{w}, \mathrm{p}_{1}$ and $\mathrm{p}_{2}$, we can use (3), as before, and determine the supply of labor of a type $\mathrm{i}$ household to be given by

$$
\mathrm{s}_{\mathrm{i}}=\mathrm{s}\left(\mathrm{w}, \mathrm{p}_{\mathrm{i}}\right)
$$

where the function $\mathrm{s}(. .$,$) is the same as before. Then, given \mathrm{w}, \mathrm{p}_{1}$ and $\mathrm{p}_{2}$, the total supply of type i workers will be

$$
\mathrm{S}_{\mathrm{i}}\left(\mathrm{w}, \mathrm{p}_{\mathrm{i}}\right)=\mathrm{h}_{\mathrm{i}} \mathrm{s}\left(\mathrm{w}, \mathrm{p}_{\mathrm{i}}\right)
$$

As before, $\mathrm{p}_{1}^{\mathrm{e}}$ and $\mathrm{p}_{2}^{\mathrm{e}}$ are rational expectations of finding a job on the part of type 1 and type 2 households if and only if

$$
p_{i}\left(D(w), S_{1}\left(w, p_{1}^{e}\right), S_{2}\left(w, p_{2}^{e}\right)\right)=p_{i}^{e}, \quad i=1,2 .
$$

Equilibrium, with or without minimum wage legislation, is defined as in Section 4. 
Now, consider an equilibrium where there is unemployment. It will be found that in households where men are unemployed, the women will be more likely to be unemployed and in households where men are employed, the women will be more likely to be employed. This occurs despite the fact that the added worker effect (as in Theorem 2) is there for each household and there is no discouragement effect. Without denying that in reality there could be certain discouragement effects that result from search costs, empirical evidence supporting it, based on the fact an unemployed person's spouse tends to be unemployed, might overstate this effect.

In addition, as stressed earlier, it seems important to measure the added worker effect as the households and their secondary workers' labor supply response to the worsening job prospects of the primary worker, instead of the actual loss of employment of the primary worker used in much of the empirical literature.

\subsection{A Note on Inflation}

There is an interesting insight that our model sheds on the relation between unemployment and inflation. Suppose an economy has a legal minimum wage at $\hat{\mathrm{w}}$ as shown in Figure 2 and suppose that the labor market equilibrates exactly at that wage with labor supply equal to $\hat{\mathrm{w} Z}$ and unemployment kz. It is usually the case that minimum wages are specified in nominal rather than real terms, and so let us assume that this is the case. Now, suppose that there is gentle inflation in the economy. This means that the minimum wage, in real terms, will slowly erode downwards. It seems reasonable to suppose that the equilibrium supply will move along the segment $\mathrm{zr}$ on the actual supply

curve. 11 Note now that, as we go from $\mathrm{z}$ to $\mathrm{r}$, we move from $\mathrm{S}(\mathrm{w}, \mathrm{p}$ "') to $\mathrm{S}(\mathrm{w}, \mathrm{p}$ "). From 
Theorem 1, we know that $\mathrm{p}^{\prime \prime}<\mathrm{p} "$. Hence $1-\mathrm{p} "{ }^{\prime}>1-\mathrm{p} "$. So as inflation occurs, unemployment will tend to fall. In other words, a minimum wage legislation, in the absence of automatic indexation, provides an explanation for a Phillips curve type relation, though inflation in our model results not just in lower unemployment but a falling rate of unemployment.

\section{Conclusion}

Whenever decision-making occurs at the level of the household (whether we conceive the household as a single decision-making unit or an arena of bargain), it is natural that what is expected to happen to one person in the labor market will affect the behavior of other members of his or her household. Hence, the aggregate labor supply curve cannot strictly be derived without knowledge of what the demand curve looks like. The aim of this paper was to formally model the dependence of supply on demand. Since many textbooks do treat the household as the basic unit of decision-making, when such books then go on to derive the supply of labor, without taking note of the demand conditions, they are committing a methodological error. We hope that this paper will help rectifying this.

This paper argues that in the presence of unemployment risk, there might be important added worker and discouragement effects. Households could send additional participants to the labor market in order to insure against the worst outcome of no labor income and there can also be situations where workers become despondent in the face of increased unemployment and cease to search for work. The empirical literature in labor economics has shown awareness of this inter-dependence and there is a body of writing 
that has looked into the 'supply response' to demand shifts. However this empirical literature was handicapped by not having an adequate theoretical structure to work on. We stressed that most existing empirical studies have tended to underestimate the added worker effect by focusing on actual employment status and neglecting expectations, and showed that they may have overestimated the discouragement effect of unemployment by ignoring household-level characteristics.

This added worker effect will increase labor supply, possibly creating a downward sloping supply curve and giving rise to surprising phenomena. One of the most interesting insights concerns the response of the labor market to wage rigidity, whether it be from minimum wage legislation or some kind of efficiency wage. In particular this paper showed that a minimum wage law can result in an overall drop in wages.

It is also worth noting that increasing the labor supply is only one way to reduce the fluctuations in income due to unemployment, borrowing and dissaving constituting other options. Hence the added worker effect is likely to be stronger for households which are credit constrained or whose credit or dissaving opportunities are more limited.

The paper also analyzed the effect of a household-level income guarantee scheme which insures worker households against the worst ravages of an economic slump. It was argued that such unemployment benefits can be justified not just in terms of equity but also efficiency.

The model developed here can be extended in several ways. For one, there are other policy interventions (for instance, differently designed guarantee schemes or 
unemployment benefits) that need to be examined. This can be useful in designing social welfare interventions.

Secondly, in constructing our model, we kept coming up against matters which, essentially, involve dynamics or at least a modicum of inter-temporal decision-making. People may, for instance, want to revise their labor supply decision after they learn what happens to the household. Of course, one then has to allow a third round of adjustment, and a fourth round and so on. Moreover, a household could try to smoothen its consumption not only by offering and withdrawing its secondary workers but by having its primary workers over work when work is available and save for the rainy season.

We made several strong assumptions to desist from getting drawn into these dynamic and intertemporal questions, not because the questions are unimportant but, because even in a simple one-period model such as ours, the interdependence between supply and demand is complex enough. We hope that modeling this carefully will in fact encourage the building of long-run dynamic models. 


\section{References}

Ashenfelter, Orley (1980). "Unemployment as Disequilibrium in a Model of Aggregate Labor Supply", Econometrica, vol. 48, pp. 547-64.

Ashenfelter, Orley and James Blum (1976). Evaluating the Labor Market Effects of Social Programs, Industrial Relations Section, Department of Economics, Princeton University, Princeton, New Jersey.

Bardhan, Pranab K. (1984). Land, Labor and Rural Poverty: Essays in Development Economics, Columbia University Press, New York.

Basu, Kaushik and Pham H. Van (1998). "The Economics of Child Labor", American Economic Review, vol. 88, pp. 412-27.

Basu, Kaushik (1999). "Child Labor: Cause, Consequence and Cure, with Remarks in International Labor Standards", Journal of Economic Literature, vol. 37, pp. 1083-1119.

Basu, Kaushik (2000). "The Intriguing Relation Between Adult Minimum Wage and Child Labor", Economic Journal, vol. 110, pp. C50-C61.

Belton M. Fleisher and George Rhodes (1976). "Unemployment and the Labor Force Participation of Married Men and Women: A Simultaneous Model", Review of Economics and Statistics, vol. 58, pp. 398-406.

Cain, Glen G. (1966). Married Women in the Labor Force: An Economic Analysis, Chicago: University of Chicago Press.

Fehr, Ernest (1986). "A Theory of Involuntary Equilibrium Unemployment", Journal of Institutional and Theoretical Economics, vol. 142, pp. 405-30.

Genicot, Garance (1998). "An Efficiency Wage Theory of Child Labor: Exploring the Implications of Some Ideas of Leibenstein and Marx", Department of Economics Working Paper No. 462, Cornell Universitiy.

Harris, John R. and Michael P. Todaro (1970). "Migration, Unemployment and Development: A Two-Sector Analysis", American Economic Review, vol. 60, pp. $126-42$.

Humphrey, Don Dougan (1940). "Alleged Additional Workers in the Measurement of Unemployment", Journal of Economic Studies, vol. 48.

Layard, Richard, M. Barton and Antonio M. Zabalza (1980). "Married Women's Participation and Hours", Economica, vol. 47, pp. 51-72. 
Leibenstein, Harvey (1950), 'Bandwagon, Snob and Veblen Effects in the Theory of Consumers' Demand', Quarterly Journal of Economics, vol. 64.

Leibenstein, Harvey (1957). Economic Backwardness and Economic Growth: Studies in the Theory of Economic Development, New York, Wiley.

Lundberg, Shelly (1985). "The Added Worker Effect", Journal of Labor Economics, vol. 3, pp. 11-37.

Maloney, Timothy J. (1987). "Employment Constraints and the Labor Supply of Married Women: A Reexamination of the Added Worker Effect", Journal of Human Resources, vol. 22, pp. 51-61.

Maloney, Timothy J. (1991). "Unobserved Variables and the Elusive Added Worker Effect', Economica, vol. 58, pp. 173-87.

Mincer, Jacob (1962). "Labor-Force Participation of Married Women: A Study of Labor Supply", in Studies of Labor Supply: Collected Essays of Jacob Mincer, vol. 2, Edward Elgard Publishing, Hants, England.

Mincer, Jacob (1966). "Labor-Force Participation and Unemployment: A Review of Recent Evidence", in Studies of Labor Supply: Collected Essay of Jacob Mincer, vol. 2, Edward Elgard Publishing, Hants, England.

Mincer, Jacob (1976). "Unemployment Effects of Minimum Wages", Journal of Political Economy, vol. 84, 87-104.

Mirrlees, James A. (1975). "A Pure Theory of Underdeveloped Economies", in L.G. Reynolds (ed.), Agriculture in Development Theory, Yale University Press, New Haven.

Rothschild, Michael and Joseph E. Stiglitz (1970). "Increasing Risk I: A Definition", Journal of Economic Theory, vol. 2, pp. 225-43.

Schlicht, Ekkehart (1978). "Labor Turnover, Wage Structure and Natural Unemployment", Zeitschrift fur die gesamte Staatswissenschaft (JITE), vol. 134, pp. 337-46.

Shapiro, Carl and Joseph E. Stiglitz (1984). "Equilibrium Unemployment as a Worker Discipline Device", American Economic Review, vol. 74, pp. 433-44.

Stiglitz, Joseph E. (1974). "Alternative Theories of Wage Determination and Unemployment in LDC's: The Labor Turnover Model", Quarterly Journal of Economics, vol. 88, pp. 194-227. 
Stiglitz, Joseph E. (1976). "The Efficiency Wage Hypothesis, Surplus Labor, and the Distribution of Income in L.D.C.s", Oxford Economic Papers, vol. 28, pp. 185207.

Tano, Doki (1993). "The Added Worker Effect", Economic Letters, vol. 43, pp. 111-17.

Veblen, Thorstein (1991). "The Theory of the Leisure Class", in Reprints of Economic Classics. The Writings of Thorstein Veblen, Fairfield, N.J.

Woytinsky, Wladimir S. (1940a). "Additional Workers and the Volume of Unemployment", Pamphlet Series No. 1, Committee on Social Security of the Social Science Research Council, Washington, D.C.

Woytinsky, Wladimir S. (1940b). "Additional Workers and the Volume of Unemployment", Journal of Political Economy, vol. 48. 


\section{Endnotes}

${ }^{1}$ In addition, an added worker effect would also arise if household members are substitutes in home production. An increase in the primary worker's non-market time would reduce the relative value of the secondary workers' non-market time, thereby inducing them to join the labor force. Note that this effect would be a response to the actual loss of employment of the primary worker. However, we will abstract from this matter here.

${ }^{2}$ An early related attempt occurred in Ashenfelter (1980).

${ }^{3}$ Our use of the indirect household utility function V(.) places no restriction on how consumption is distributed within the household. We could, for instance, begin by assuming that the household utility from its $\mathrm{m}$ members consuming $\mathrm{x}_{1}, \ldots, \mathrm{x}_{\mathrm{m}}$ is given by $\phi\left(\mathrm{x}_{1}, \ldots, \mathrm{x}_{\mathrm{m}}\right)$. In that case $\mathrm{V}(\mathrm{Y})$ is the solution to the following problem:

$$
\max _{\mathrm{x}_{1}, \ldots, \mathrm{x}_{\mathrm{m}}} \phi\left(\mathrm{x}_{1}, \ldots, \mathrm{x}_{\mathrm{m}}\right), \text { subject to } \sum_{\mathrm{i}=1}^{\mathrm{m}} \mathrm{x}_{\mathrm{i}} \leq \mathrm{Y}
$$

The restriction that we place on the form of $\mathrm{V}(\mathrm{Y})$ can easily be derived from the standard restrictions on $\phi$ It is in particular easy to see that if $\phi_{\mathrm{i}}>0$ and $\phi_{\mathrm{ii}}<0$ for all $\mathrm{i}$, then $\mathrm{V}^{\prime}>0$ and $\mathrm{V}^{\prime \prime}<0$

${ }^{4}$ It may appear at first sight that the choice of $\mathrm{D}$ will affect $\alpha$. But once we recognize that our model is mimicking a case with thousands of small firms, it seems no longer surprising to assume that the total number of jobs offered is unchanged by a single firm varying its number of offers. It is easy to make the model more realistic by assuming that there are many firms, taking decisions atomistically. But since that would not change our results, it seems worthwhile using the simplifying assumption of there being one firm. 
${ }^{5}$ See Genicot (1998) for some implications of relaxing these assumptions.

${ }^{6}$ For reasons similar to the argument in Rothschild and Stiglitz (1970).

${ }^{7}$ It should be stressed that this is currently a conjecture since we have not yet proved formally that $\mathrm{b}$ dominates $\mathrm{z}$.

${ }^{8}$ In Third World countries, child unemployment rates often differ markedly from adult unemployment rates. This can however have causes very different from the ones discussed here (see Basu, 2000).

${ }^{9}$ See e.g. Mincer, 1966; Maloney, 1991.

${ }^{10}$ Cain, 1966; Lundberg, 1985; Tano, 1993.

${ }^{11}$ In other words, though the labor supply correspondence is multi-valued around $\hat{\mathrm{w}}$, we are assuming that, as $\hat{\mathrm{w}}$ changes a little, supply will vary continuously as long as that were possible. 